\title{
TYPICAL FLIES
}

\section{A PHOTOGRAPHIC ATLAS}

\author{
BY \\ E. K. PEARCE
}

SECOND SERIES

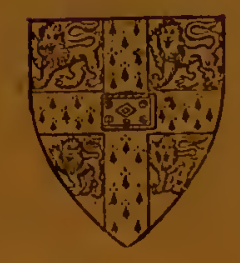

CAMBRIDGE

AT THE UNIVERSITY PRESS

I 92 I 




TYPICAL FLIES 
CAMBRIDGE UNIVERSITY PRESS

C. F. CLAY, Manager

LONDON : FETTER LANE, E.C. 4

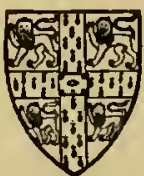

LONDON : H. K. LEWIS AND CO, LTD., 136, Gower Street, W.C. 1

LONDON : WHELDON \& WESLEY, LTD., 28, Essex Street, Strand

NEW YORK : THE MACMILLAN CO. BOMBAY

CALCUTTA MACMILLAN AND CO., Ltd. MADRAS

TORONTO : THE MACMILLAN CO. OF CANADA, LTD.

TOKYO : MARUZEN-KABUSHIKI-KAISHA

ALL RIGHTS RESERVED 


\title{
TYPICAL FLIES
}

\section{A PHOTOGRAPHIC ATLAS}

\author{
thet Bye fine \\ E. K. PEARCE
}

SECOND SERIES

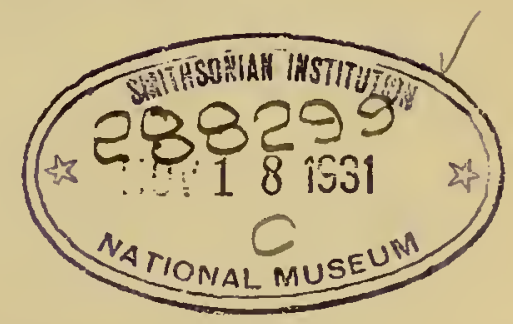

CAMBRIDGE

AT THE UNIVERSITY PRESS

I 92 I 
NoV $13 \mathrm{ks}$

n.......... 


\section{PREFACE TO THE SECOND SERIES}

T HIS supplementary volume of Typical Flies endeavours to complete the series of British Types, which, before the Great War, Professor Theobald was good enough to select and suggest as a sort of itinerary. And his notes in both volumes, especially those on larvae in the present volume, have greatly added to their value. Thanks are due in addition to the British Museum; to the Museum of Mr Rothschild at Tring, for the loan of micro-slides of the Nycteribiidae; and to $\mathrm{Mr} \mathrm{H}$. Waddington, of Bournemouth, for micro-slides of the Culicidae. To the late Mr F. C. Adams, of the New Forest, and to Mr N. D. F. Pearce, of Grantchester, for various notes and specimens captured by them? The only specimens which were included in the original list, and have not been obtained sufficiently well set for photography, are those of Medeterus micaceus, Agromyza lutea, Diplosis pyrivora, and of Oscinis frit, to be added later.

To Mr Harwood, of Sudbury (Suffolk), I am again greatly indebted for many specimens, especially those of Trypetidae ${ }^{2}$, and seq. There appeared to be no recent illustrations of these beautiful flies and similar species, or even of some rare and common flies, of which identification is difficult. So these, too, have been included in this little volume.

It is not claimed that the venation is always clear; that would be difficult to secure in many cases: but every effort has been made to give a clue to the collector. Whenever possible a comparison with actual named specimens in collections and museums, or with lens, is desirable. The requirements of the Dipterist have been dealt with in the previous volume. They include a good net, bottles, pins, fine brushes, and forceps, for setting. Setting boards, killing bottles, corklined boxes for keeping specimens (in these expensive days of cabinets), a low-power microscope, and a good hand lens are desiderata. The hours for collecting are those of calm, March to October; a warm sun is essential. For unknown reasons specimens not only inhabit

1 I greatly regret to hear of the death of Mr Adams since this series of Typical Flies went to press.

2 In the Entomologist's Record and Journal of Variation Mr T. C. Collins deals with the variation in wing markings of Trypetidae, stating that the banded mottled wings constitute specified and even generic characters. 
certain districts, but as often desert them for even a term of years. Nevertheless, it is in well-known resorts that the capture of certain species is alone possible. A classification of Brauer will be found in this volume, as in its predecessor; a cross marks the specimens contained in this volume, and a star intimates they will be found in the preceding volume. It is hoped that this little book may not be in vain in inducing students to commence a study of wide possibilities.

The following books may be of use to the student:

Theobald's Monographs of the Culicidae. (British Museum: some of which are out of print.)

Verrall's List of British Diptera.

" British Flies (two volumes).

Austen's Bloodsucking Flies. (British Museum of Natural History.)

Parasitology, Vol. Ix, No. 4. July 27, 1917. C.U.P. Notes on Nycteribiidae.

Staveley's British Insects.

Instructions for Collcctors. (British Museum.)

Insects at Home. (Wood.)

A map showing known distribution of Anopheles mosquitos. (British Museum.)

In the Exhibited Series of Insects in the Department of Zoology, British Museum (Natural History), Cromwell Road, S.IV., will be found a short series of British Diptera : those in table cases having fine enlarged coloured illustrations on the lids of the cases, of great use to students-the main collections of the Museum being reserved elsewhere.

E. K. PEARCE.

KEMPSTON, BOURNEMOUTH, Aug. 16th, 1921. 


\section{PREFACE TO THE FIRST SERIES}

$T$ HE study of Diptera (two-winged flies) is rendered peculiarly difficult by the lack of elementary treatises on the subject. Certain groups are fully treated in the two large (and costly) volumes published by the late Mr Verrall, there are a few scattered papers in various magazines, and one or two monographs (such as Lowne's on the Blowfly); but there is nothing to compare with the numerous manuals dealing with Lepidoptera and Coleoptera, to name two orders only. This little book does not claim to fill the gap, but it is hoped that it may be of some use to the beginner, and attract attention to an order which possesses great interest, and is moreover of much economic importance. It is chiefly a picture book, as pictures appeal more to the eye than many pages of letterpress; and an injportant dipterous character - the venation of the wings - can be rendered with fidelity in a photograph.

I have found it difficult to obtain specimens set sufficiently flat for photographic reproduction; since, in photographing on the enlarged scale required, no amount of "stopping down" will produce an image sharp all over, unless the subject be fairly in one plane: in addition to this, some species when set and dried shrivel up, and give but a poor idea of their appearance when fresh. This of course chiefly applies to the bodies of flies, the wings and legs are not so affected.

Flies may be taken with the usual entomological net, preferably a green one, as less likely to cause alarm than a white one. Mosquito netting, which may be dyed the required colour, is much better than green leno. The net should be fairly large, but light and easily managed, as many flies are very swift and strong on the wing. When caught, the fly may be transferred to a glass bottomed entomological box: a good supply should be carried, and it is better that only one specimen be placed in a box. On returning home the flies may be killed in a laurel bottle, care being taken that the leaves do not become mildewed, which would probably ruin the specimens; a circular piece of white blotting paper should be placed over the leaves, and frequently renewed. Flies should remain in the bottle till they are thoroughly relaxed, which will require a day or two; if left too long they become rotten 
and easily break whilst setting. Narrow boards, such as are used for the smallest lepidoptera, will be suitable for large and medium sized flies; small ones may be set on strips of flat cork, covered with thin white paper. Entomological forceps will be needed to insert the pin in the thorax of the fly; I prefer these curved, as they are also useful for moving pinned specimens. If the flies are to be photographed the pin must be cut off as short as possible above the thorax, and the cut end blackened with a touch of "matt black." No. 20 pins will be useful for most flies, though the large species require something stronger, whilst the very small ones, if pinned at all, require the finest silver pins obtainable. Taylor, New Hall Works, Birmingham, will supply a sample card of pins. For setting, strips and triangles of stiff writing paper, to hold legs and wings in place, and a stiff sable paint-brush, a few handled bristles and a fine needle or two, also handled, will do all that is required: a lens is indispensable in setting small flies, and may with advantage be mounted on a simple stand to leave both hands free. Some flies, especially the Tachinidae, are very brittle: care must be taken in manipulating them. Culicidae should be set and photographed as quickly as possible, they very soon shrivel. Other flies may remain about ten days on the setting boards. As to numbers, half a dozen specimens should be ample, both sexes being represented, where possible. Fewer will often have to suffice with rare species, and for purposes of photography one well set specimen would be sufficient, were it not for the ever present risk of damage in moving from the store box: the slightest touch or jar will often cause the loss of a leg or antenna, and the attempt to replace these is seldom successful.

Store boxes may be had in many sizes (Io $\times 8$ inches is as good as any); whatever size is used should be adhered to, as far as possible, for the sake of uniformity. They should be carefully examined for mites, a great enemy to the collector; even new boxes are sometimes contaminated. In sending flies by post it is well to use two boxes, pinning them well into the inner, and supporting them by extra pins if possible; then packing the box with shavings inside a larger one. The label will of course be tied on. When finally pinning flies into the store box it is essential to use a small label giving date and locality, which can be pinned, written side down, by the same pin as the specimen. The name, etc. of the fly is written on a second label and pinned behind it in the box: the sex should be marked, where known, and a number added to correspond with that in a notebook, where fuller details may be recorded. Flies should be stored in a cool 
dry place, free from accidental jars and careless handling. Naphthalin wrapped in a piece of net should be pinned in a corner of the box as a guard against mites, the great enemy of the dipterist as of the entomologist in general.

The chief season for collecting in this country is from March till October, the sunny forenoon being the best time. Windy days are very unproductive. Even well-known and good localities are sometimes a blank, from causes we do not know, for flies seem very capricious in their habits. But, like other creatures, they have special haunts where they may usually be found at the proper season, and where they may be expected to occur if carefully searched for. Considerable experience in their habits and localities is needed by the collector. Generally speaking, umbelliferous plants, also bramble, hawthorn and ivy bloom seem to be most attractive. Flies often settle upon gate-posts, railings, and tree-trunks, especially if wounded or decayed. Others frequent salt-marshes and swamps, ponds and river-sides; whilst heath-lands, sheepruns, bare hot sandy areas and commons attract others. Horse and cattle droppings and decomposing animal and vegetable matter are well-known baits for many species. Others attack living animals, not excepting man; and certain flies prey on insects and spiders. Should horses or cattle be approached for the purpose of taking flies, much care must be exercised, as a net will generally stampede them; it is difficult to employ it to advantage under such conditions.

This little book has received the kind encouragement of many entomologists, among whom I may mention Professor Nuttall and Mr Warburton, both of Cambridge. Much practical help in the selection of species, and information as to types selected and their larvae, has been afforded by the kindness of Professor Theobald, whose assistance, it is hoped, has added greatly to the utility of this book. Thanks are also due to Mr Harwood, of Colchester, for the fine specimens of diptera which he has furnished for the photographs herewith presented. It has not always been possible to do them justice, owing to the difficulties previously noted as besetting the photographer. Mr H. Waddington kindly supplied some fine microscopic slides. The author's brother, Mr N. D. F. Pearce, has also helped with the illustrations, as to the success of which the reader must be left to judge. Acknowledgement has been made in every case, it is thought, where help has been received: and if this effort is successful it is hoped that it may be some day supplemented by a further series of pictures, to fill a few gaps that were unavoidable in the present volume. 
The life history (ovum, larva, pupa) of many of the species shown is yet to be traced by entomologists. Measurements are given in every case in millimetres $(25 \mathrm{~mm} .=\mathrm{I}$ inch), the first dimension being the length of the fly, and the second the expanse of wings. For various reasons it has not been found possible to reproduce the specimens on one uniform scale: the same difficulty was met with by Dr Michael in illustrating the Oribatidae.

E. K. PEARCE.

BOURNEMOUTH.

June 1915.

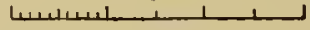

Scale of 3 centimetres of which one is divided into ro millimetres. 


\section{BRAUER'S CLASSIFICATION OF DIPTERA}

( + A cross denotes that the family is illustrated in this book. * An asterisk intimates they will be found in the preceding volume.)

\section{Sub-order I. ORTHORRHAPHA}

Larva with a distinct head. Pupa obtected.

The adult escapes from the pupal skin by a straight dorsal slit which may be transverse but is more usually longitudinal. Imago lacks the frontal lunule and ptilinum.

\section{Sub-order 2. CYCLORRHAPHA}

Larva without any distinct head. The Pupa coarctate.

The adult escapes from the puparium through a more or less round opening at the anterior end. Frontal lunule present ; ptilinum usually present.

\section{Sub-order I, ORTHORRHAPHA}

\section{Section I. NEMATOCERA}

Antennae long and thread-like, composed of many similar or very similar segments. The maxillary palpi usually elongate and flexible of from 2 to 5 segments. Second long vein often forked.

\section{Section II. BRACHYCERA}

Antennae usually of three segments, the third usually elongated and sometimes composed of a number of indistinct sub-segments and often bearing a style or arista. Maxillary palpi of $\mathrm{I}$ to 2 segments, not flexible. Second long vein not forked. Squamae completely concealing the halteres. 
I. THE ORTHORRHAPHA. Section I. NEMATOCERA contain the following families:

*I. ${ }^{1}$ Pulicidae (Fleas).

*2. Cecidomyidae (Gall Midges).

$\dagger^{*}$ 3. Mycetophilidae (Fungus Gnats).

†*4. Bibionidae (Fever Flies, St Mark's Flies).

†*5. Simuliidae (Sand Flies).

*6. Chironomidae (Midges).

7. Orphnephilidae.

†8. Psychodidae (Owl Midges).

t*$^{*}$. Culicidae (Mosquitoes).

tro. Dixidae.

*I I. Ptychopteridae (False Daddy Long Legs).

*I2. Limnobiidae (False Daddy Long Legs).

†* I 3. Tipulidae (True Daddy Long Legs).

* 4. Rhyphidae (Window Flies).

Section II. BRACHYCERA

†*I 5. Stratiomyidae (Chameleon Flies).

†*I6. Tabanidae (Gad Flies).

*I7. Leptidae (Leptis Flies).

†*I8. Asilidae (Robber Flies).

†*I9. Bombylidae.

*2o. Therevidae.

†2 I. Scenopinidae.

+22. Cyrtidae.

†*23. Empidae (Empis Flies).

$\dagger^{*} 24$. Dolichopodidae.

†25. Lonchopteridae.

2. THE CYCLORRHAPHA. Section I. ASCHIZA

Frontal lunule more or less indefinite; no frontal suture.

*26. Platypezidae.

†27. Pipunculidae.

†*28. Syrphidae (Hover Flies).

1 These are by some raised to the rank of an order called Aphaniptera or Siphonapiera, but there is no reason whatever for separating the Fleas or Pulicidae from the Diptera. 


\section{Section II. SCHIZOPHORA}

Frontal lunule and frontal suture marked.

Sub-section A. MuscoIDEA

Produce ova as a rule.

Sub-section B. PUPIPARA

Produce fully matured larvae.

Sub-section A. MuscoIdEA

Series $a$. Acalyptrata

Squamae small, not concealing the halteres.

Series b. Calyptrata

Squamae concealing the halteres.

Section II. SCHIZOPHORA

Sub-section A. Muscoidea. Series a. Acalyptrata

*29. Conopidae.

†*30. Cordyluridae.

31. Phycodromidae.

32. Helomyzidae.

33. Heteroneuridae.

†*34. Sciomyzidae.

†35. Psilidae.

36. Micropezidae.

†37. Ortalidae.

†*38. Trypetidae.

†39. Lonchaeidae.

40. Sapromyzidae.

t4I. Opomyzidae.

42. Sepsidae.

†43. Piophilidae (Cheese Flies, etc.).

44. Geomyzidae.

45. Ephydridac.

†46. Drosophilidae.

*47. Chloropidae (Gout Flies).

48. Milichidae.

49. Agromyzidae.

†50. Phytomyzidae. 
51. Astiadae.

†52. Borboridae.

†53. Phoridae.

Sub-section A. MuscoineA. Series b. Calyptrata.

$\dagger^{*} 54$. Oestridae (Warble Flies).

†*55. ${ }^{1}$ Tachinidae (Tachina Flies).

$\dagger^{*} 56$. Muscidae (House Flies, etc.).

+*57. Anthomyidae (Root-feeding Maggots, etc.).

Sub-section B. PUPIPARA

†*58. Hippoboscidae (Forest Flies).

†59. Braulidae (Bee Flies).

†60. Nycteribiidae (Bat Flies).

1 The Sarcophaginae and Dexinae are sometimes separated from the Tachinidae as two separate families. 
Typical Flies. Second Series.

\section{ERRATA}

Figs. 46, 47. For Anthrax circumdatus read Villa circumdatu $\mathrm{Mg}$.

Fig. 48. For Habitat of Anthrax circumdatus read Habitat of Villa circumdata.

Fig. 72. For Spilogaster Zöe oै read Spilographa Zöe Mg. oै

Fig. 91. For Spilographa Zöe MIg. ठ̀ read Spilographa Zöe Mg. + 



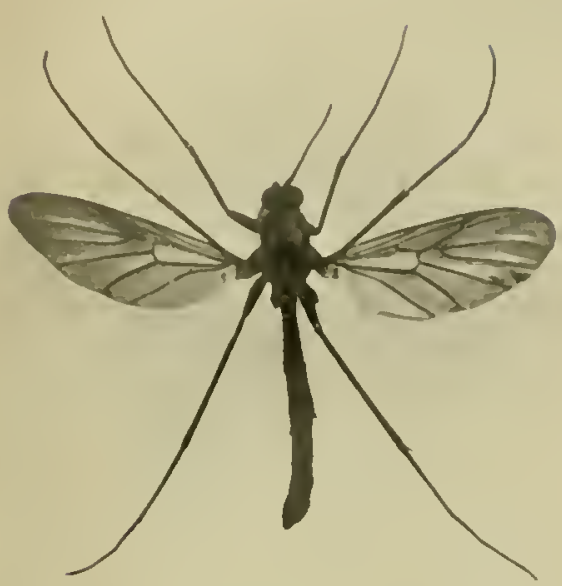

Fis. 1. Matyua mareminta 11 s. $8 \times 12 \mathrm{~mm}$. Found by sweeping. Ilost species inhabit woods and thickets. The larvac of Plutyura feed on fungi. "Appearance in the New Forest, spasmodic." (Adams.)

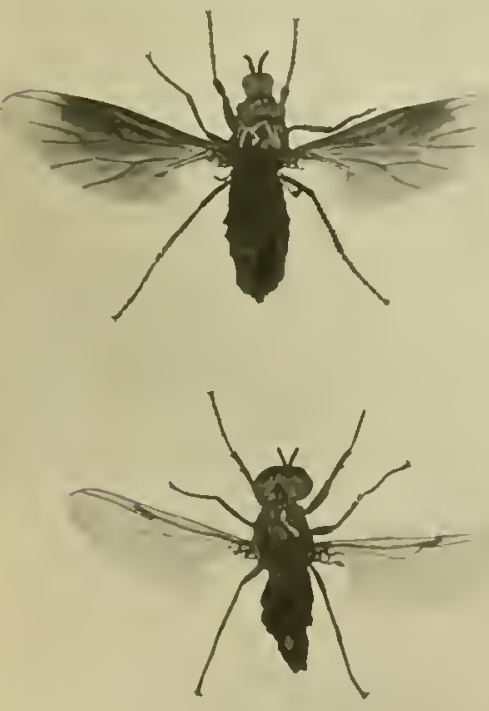

Fis. 2. Sartopse notufiz L. $\$ \times 7 \times 5 \mathrm{~mm}$. l'lentiful on II indows end of May. The larvae live on vegetable and decaying matter. They are long and fusiform and show two points at the sides of the prothorax, and of the cight basal segments of the aldomen, which ends in two rather long divergent setae. (Theobald.)

Fig. 3. llitophus fibrilis L. of $+\times 9$ mun., $+5 \times 11$ min. Abundant on Wild l'arsnip, though named fibrilis by Linnacus, owing to the generil opinion in Sweden that the $\mathrm{Hy}$ resorted to houses where intermittent fever existed. Curtis states that this species causes much mischief in gardens. The socalled fever Hy gets into Hop cones in Kent now. and then, and causes loss by destroying their brightness. The larvac live ju all manner of roots besides hops, and do no little clamage. (Theobald.) 


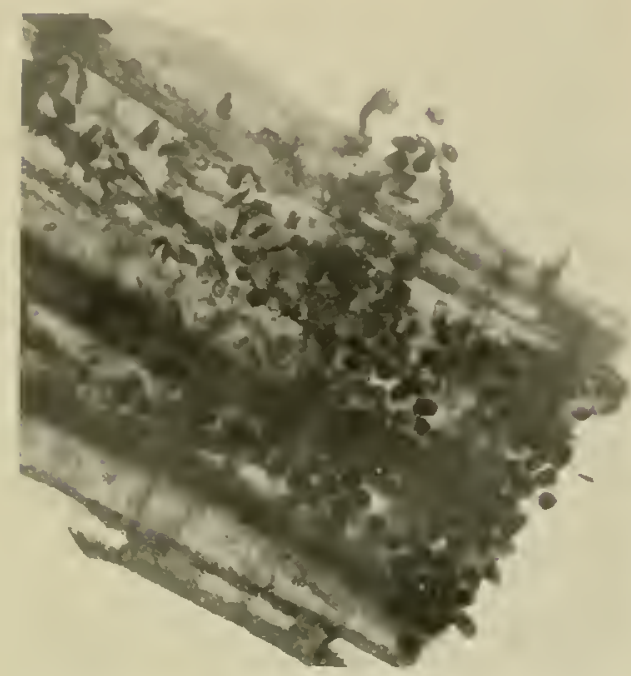

Fig. 4. Ova, simulium cincrem Ltr.

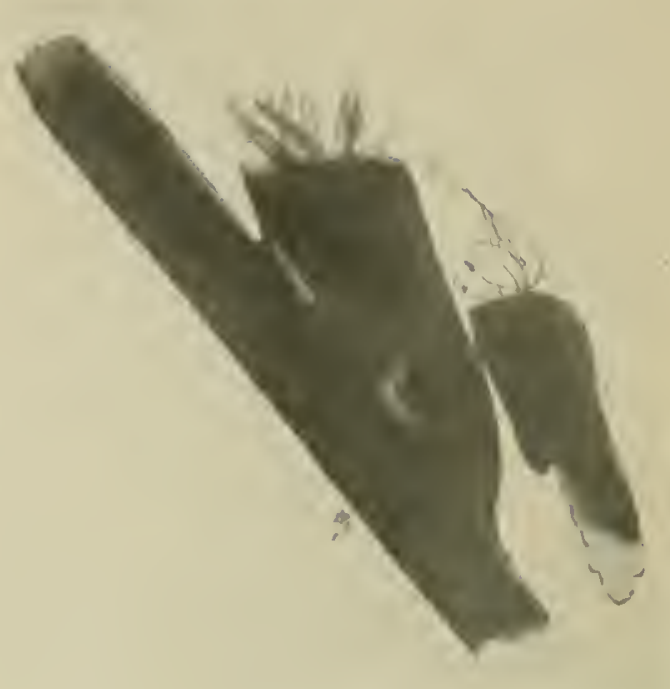

Fig. 5. Pups, vimulium.
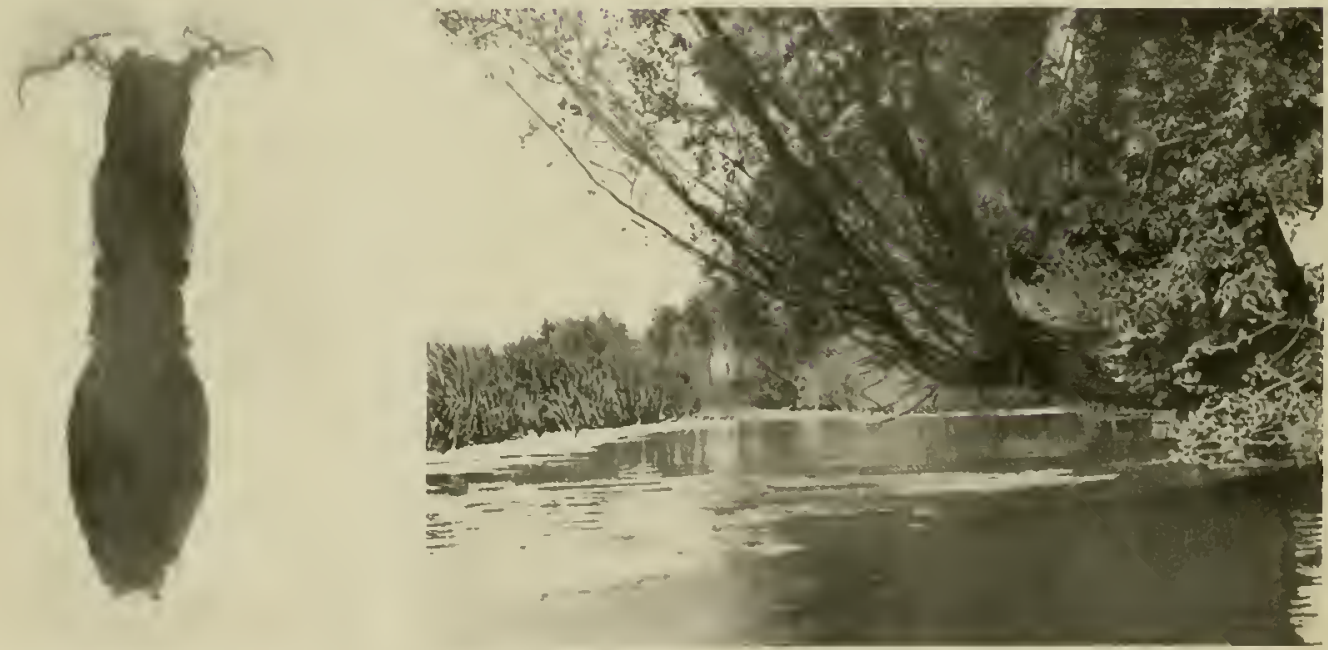

Fig. 6. Larva, Simulium.

Fig. 7. Habitat, simulium. (N. D. F. I'.)

Figs. 4, 5, 6, 7. Simulium ineremm Ltr. Larva +5 mm., Pupa +5 mm., Ova, area, 4 mm. Ilabit.lt in the Bourn lirook, (irantchester. Sand flies are abundant in damp and sandy and marshy places, and ittack man and animals ats mosquitoes do. (See Typicnl Flics, fig. 1 I.) 


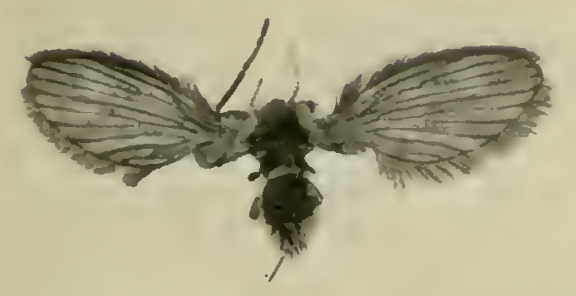

Fig. 8. Pericomu compta kat. $2 \times 8 \%$ mm. Rarely sucks blond: larvae aquatic. Larrae of P'ricoma have 2 rows of curved seins down the body.

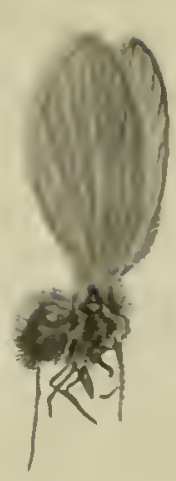

Figr. 9. Psychate phalaenoides L. 12 xi. 1 Sgr. + mm. from tip of wing to base of abdomen. Lavae live in rotting vegetable matter and dung; the pupae inactive, with 2 long tubes like antenna stigmata. The abdomen tapering. (Therobald.)

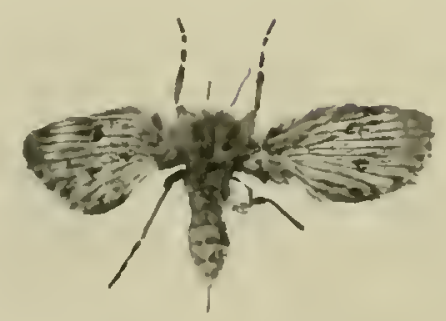

Fig. 10. Psychode sexpunctata Curt. $3 \times 7$ mm. On windows in April. The larvae live in dry cowdung. They are long, subfusiform and depressed, with a slender straight cylindrical tail, longer than the preceding segment. (Figured by Bouche and II. Perrin.) (Theobald.) Grantchester. 


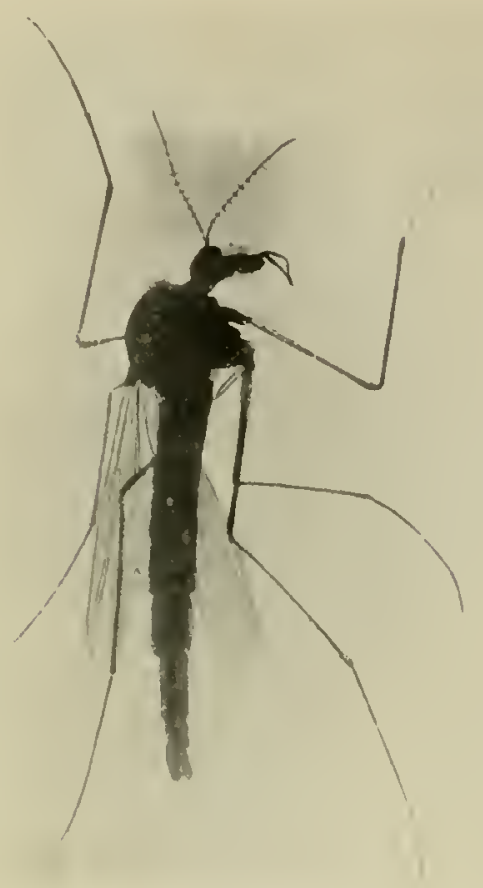

Fig. 11.

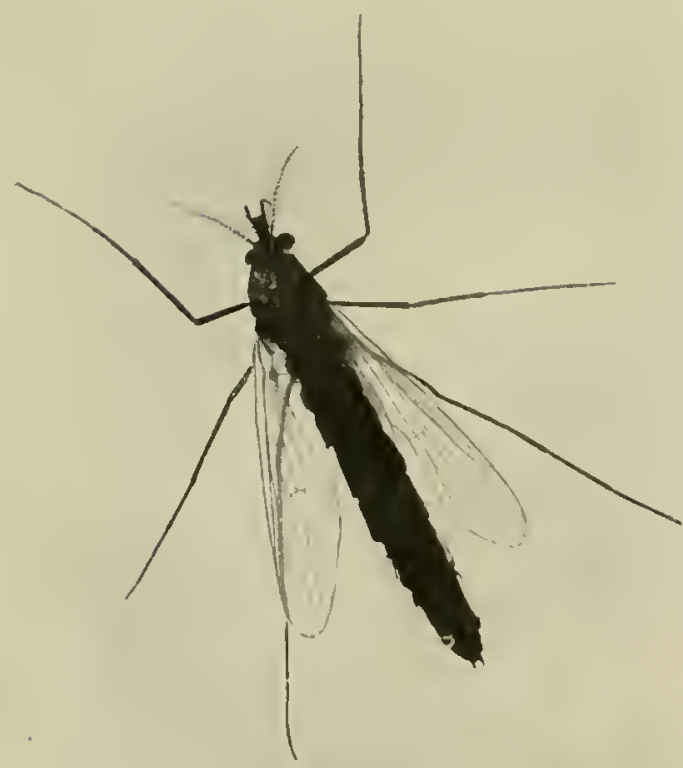

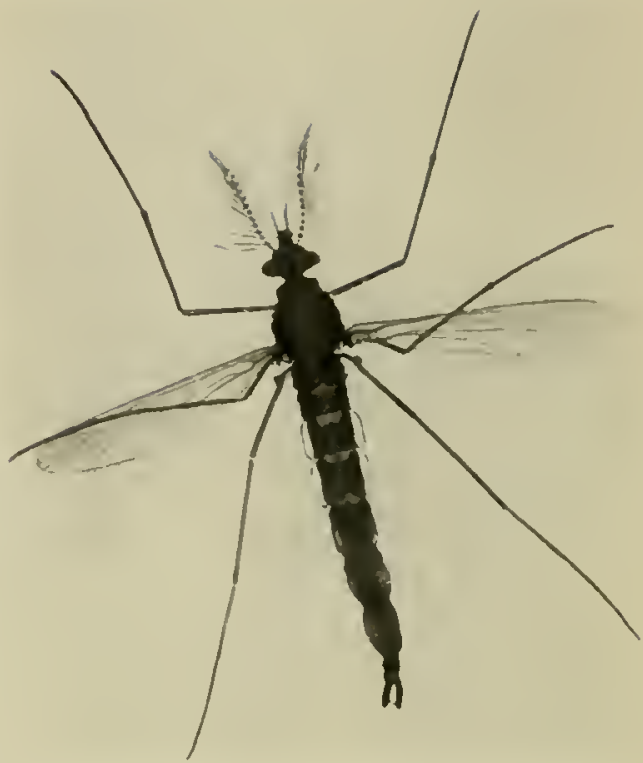

Fig. 12.

Figs. 11, 12, and 13. Conethra plumicomis F.

Fig. 11 . \& $6 \mathrm{~mm}$. to end of abdomen.

Fig. 12. के $6 \times 9$ mm.

Figr I3. o with wings closed, wings $5 \mathrm{~mm}$.

The lava of Corethra catches prey with its antennae, sweeping as do others of the Culicidae. (Figs. II, I2, I3 micro-mounts, W'addington.)

Fig. 13. 
ORTHORRHAPHA

NEMATOCERA

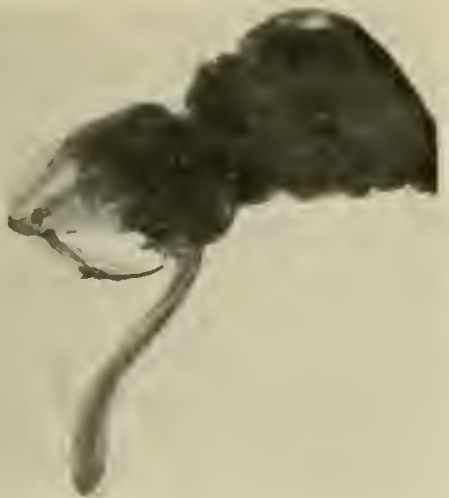

Fig. 1t. Larsa, Corethro. Introvert, plain.

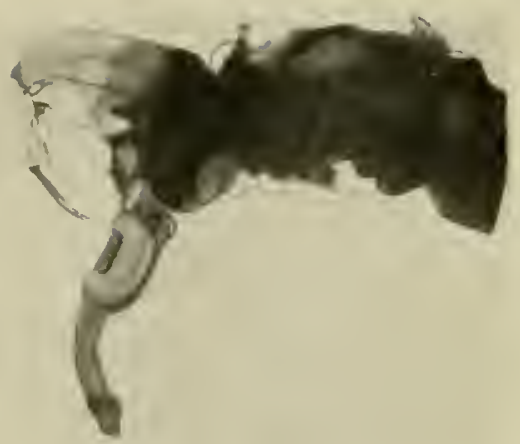

Figs. 15. Lawa, Corithra. Introvert, with included air vesicle.

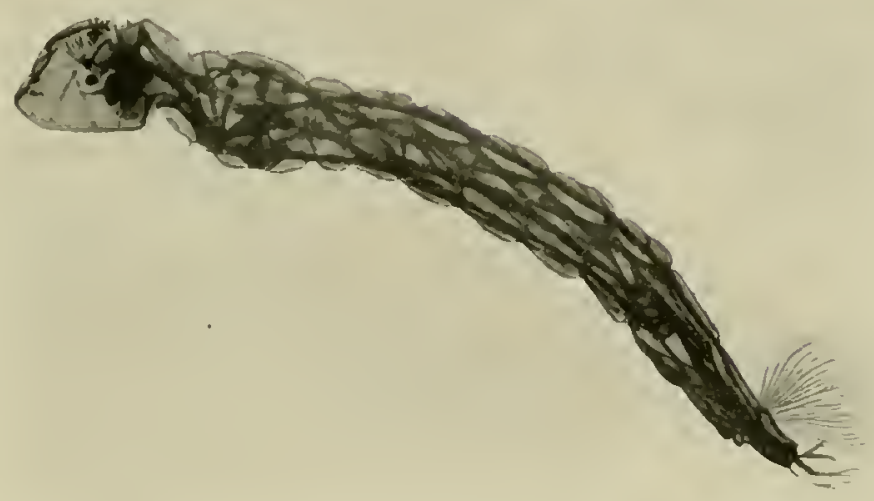

Fig. I6. Larva, Corvthro.

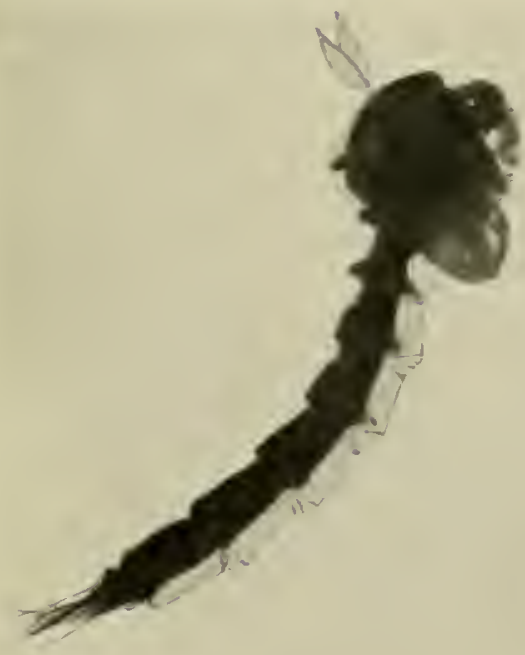

Figs. 14-17. Corthra plumicornis $\mathrm{F}$.

Fig. 14. Larva showing introvert $2.5 \mathrm{~mm}$. from back of head to end of introvert.

Fig. 15. Larva showing proboscis $3 \mathrm{~mm}$. from back of head to end of proboscis.

lig. 16. Transparent larra, $7 \mathrm{~mm}$.

Fis. 17. Pupa, 7 mm.

(Micro-slides, W"addington.)

Fig. 17. l'upa, Conthro. 


\section{NHMATOCERA}

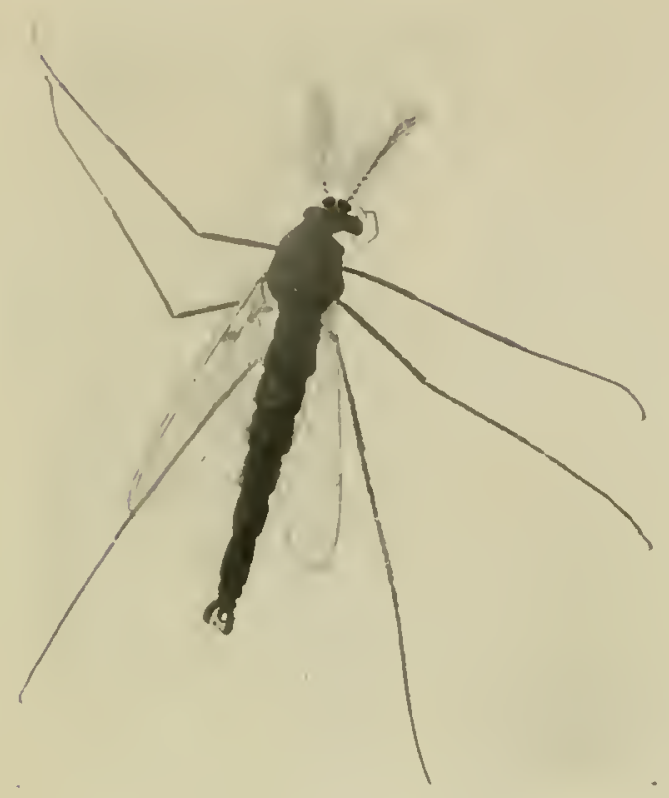

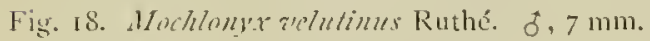

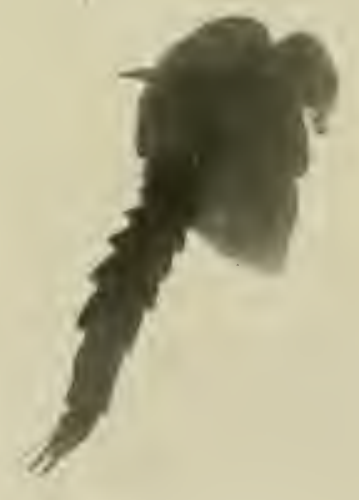

Fig. 20.

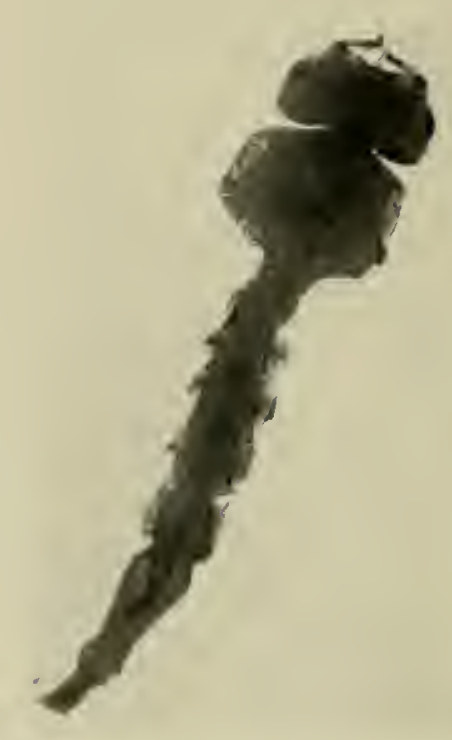

Fig. 19. Larva, Mochlonys. $6 \mathrm{~mm}$.

Fig. 20. Pupa, Mochlony.x. $+5 \mathrm{~mm}$. (Micro-slides, Wadrlington.)

The larvae of Mochlonyz are found resting on water in lbournemouth neighbourhood. Second breathing tulse out of focus and not shown. 


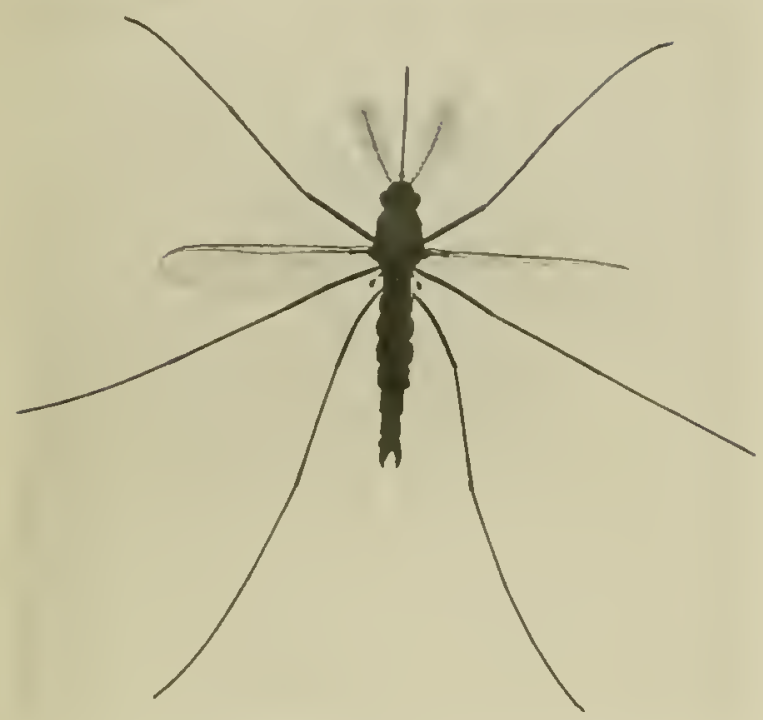

Fin. 21. Aerles cincrens . Ig $+\times 7 \mathrm{~mm}$.

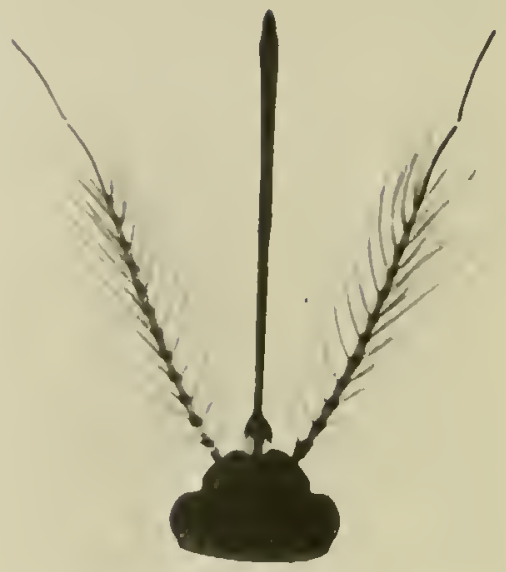

Fig. 22. Antennac of sliks cinvizs, $1.5 \mathrm{~mm}$. (Micro-slides, Nadelington.)
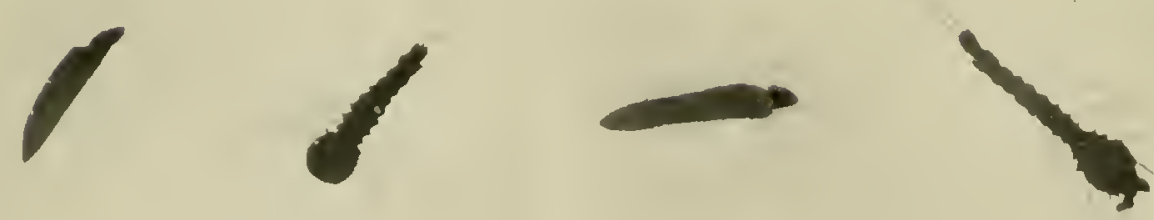

6

c

$d$

Fig. 23. Anophiles. (a) Onum showing emergence exit, $;$ mm.; (b) larva just emerged, $;$ mm. (bred

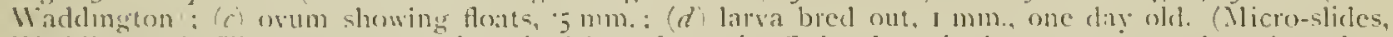
IVaddingtom.) The ova are not deposited in rafts as in Culex, but singly amonest weed, and tend to arrange in zroups or stars, coming together after deposition perhaps in at "olar Star artangement." (Wadelington. White when deposited, turn rlark rapidty. Note air cells at sides ref ovum, lig. 2 . Cp. with

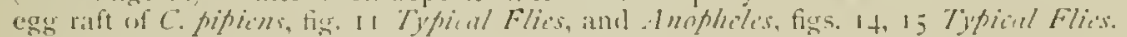




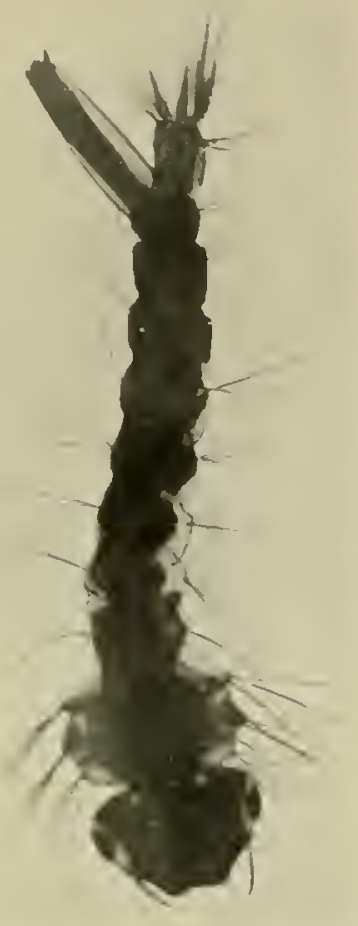

Fig. 24.

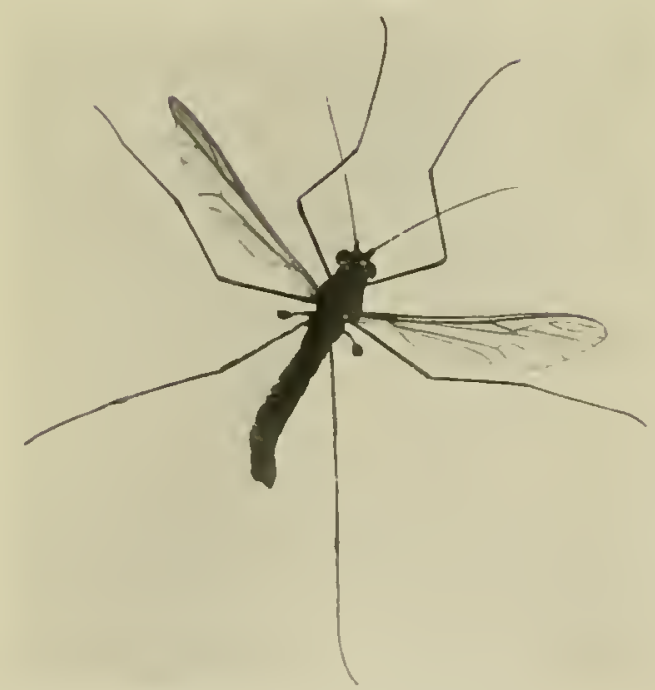

Fig. 26. Dixe . Mg. $25 \times 5$ mm. Bred Waddington from kempston fountain. Larrae aquatic, resemble somewhat those of mosyuitoes. Flies found in bushy, morst places, and dance in swarms in the air. (Theobillel.)

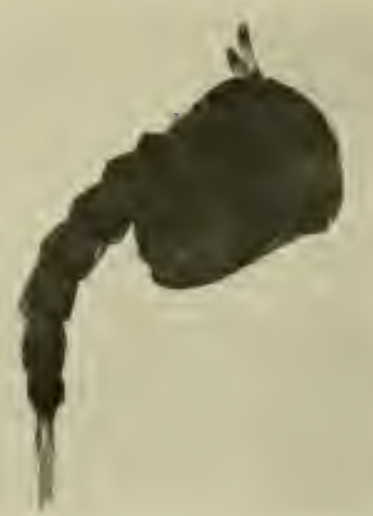

Fig. 25.

Fing. 24. Larva, Culex atexans. $7 \mathrm{~mm}$. Fig. 25. J'upa, Culex a'crats. $45 \mathrm{~mm}$. (Micro-slides, Waddington.)

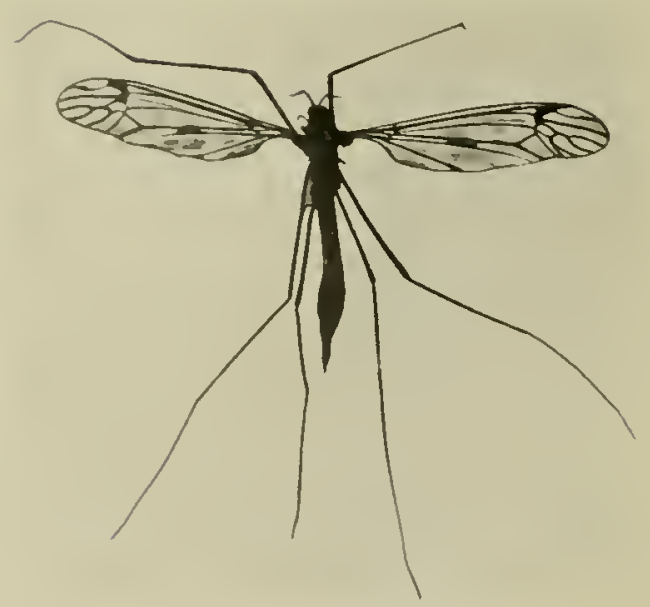

Fig. 27. Tipula memoratu .Ig. $14 \times 30 \mathrm{~mm}$. 1)umbartous. 
NEMATOCERA

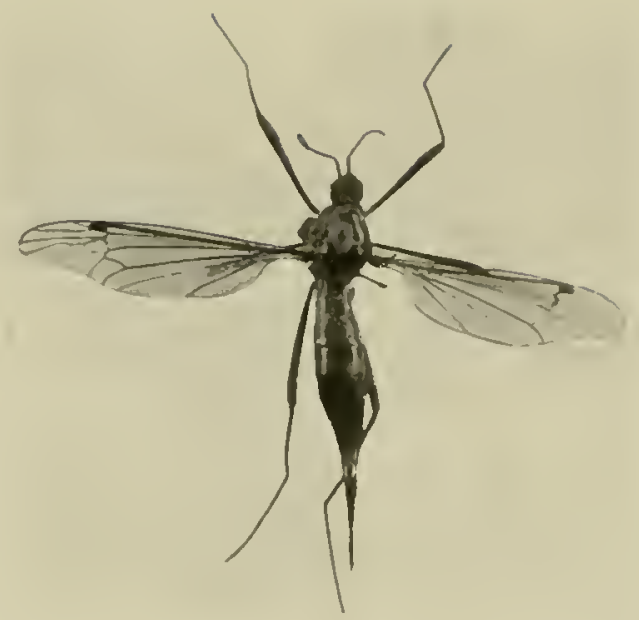

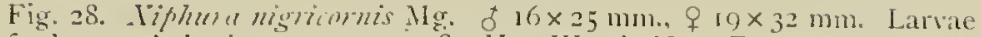
feed on oak borings. 23 \% 1908. Hut Wvod, New Furest. (Beck.) A scarce species.

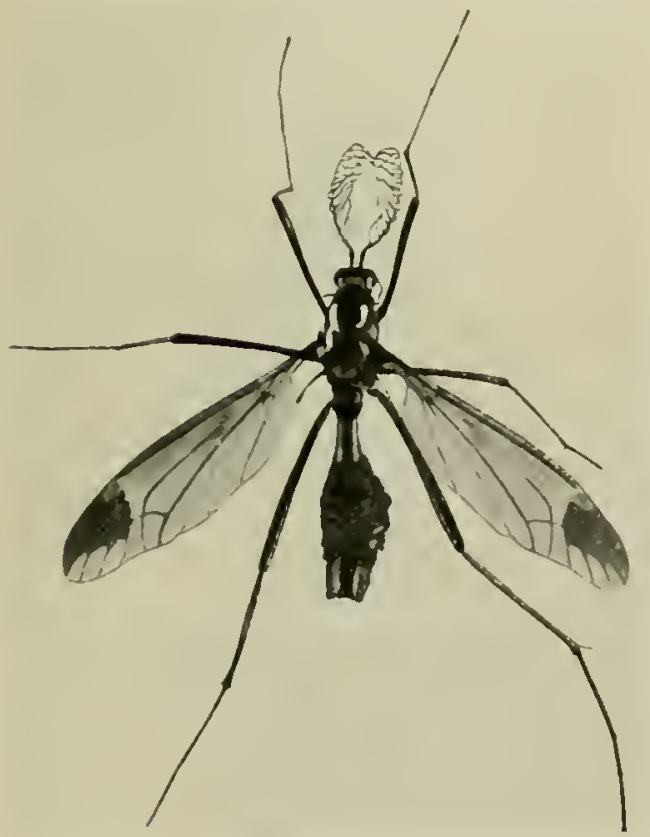

Fig. 29. Cteruphlone nimute Nig. of.

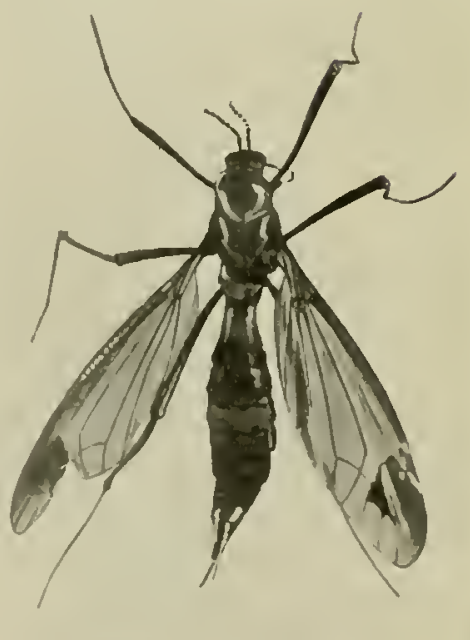

Fig. 3o. Clenophowe ormater .1yg. \&. lired by Ho shinp. New Forest, from of $16 \mathrm{~mm}$. Wings each
pupae in rotten tree. 


\section{BRACHYCERA}
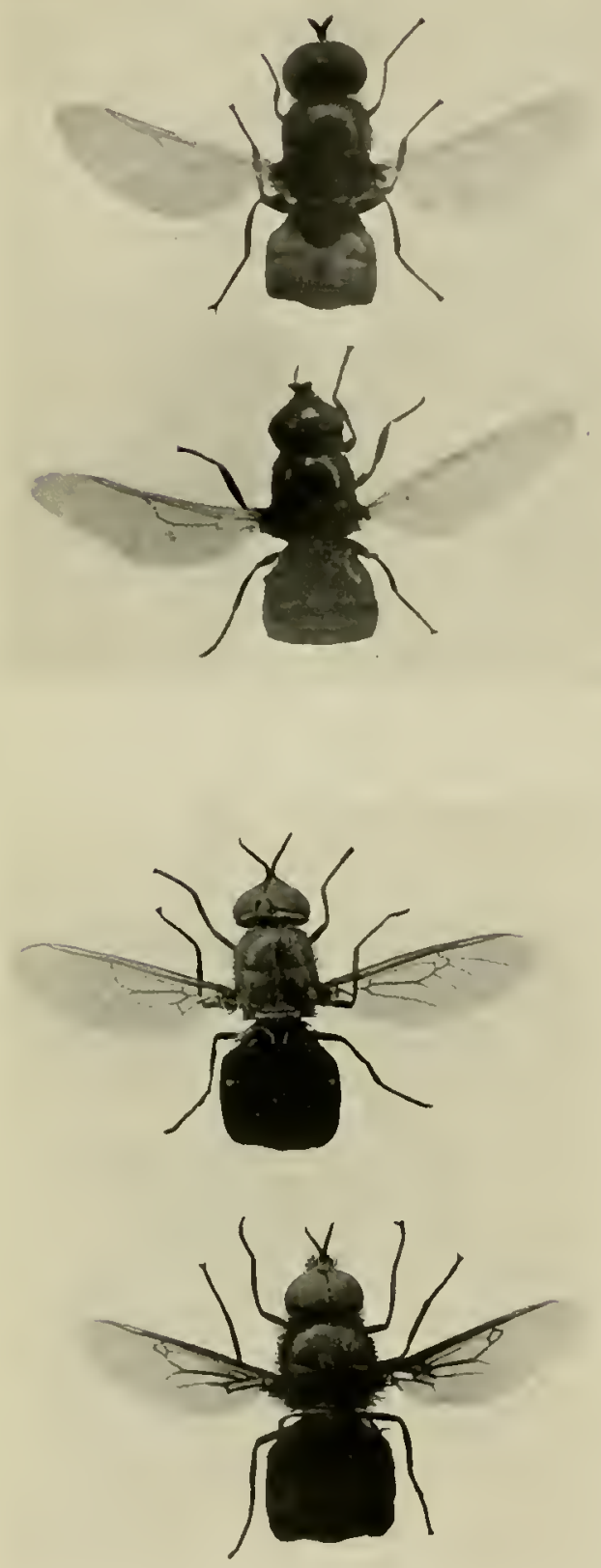

Fig. 32. Odontomvia tisrinu F. of $8.5 \times 17 \mathrm{~mm}$., $98 \times 16 \mathrm{~mm}$. Taken hovering over waterplants and about flowers of $1 \mathrm{~V}$ ater Buttercup (Ramunilus scelerufus). (Harwood.)
Fig. 31. Vemotelus notalus Ztt. o $5 \times 11 \mathrm{~mm}$. . ${ }^{5} \times 12 \mathrm{~mm}$. of cream-coloured abdomen, spotted with black. O abdomen almost wholly black. Often found in company of $N$. uliginosus. Sometimes in great numbers on the salt marshes in the Thanes Estuary. This extends to the mouth of the Colne kiver. These flies are slow in movement, and are found on flowers, rushes, and grass. St Osyth, E. Coast. Harwood. 

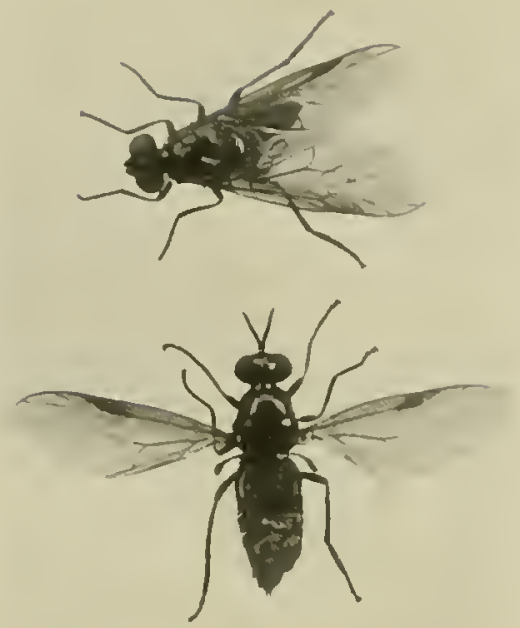

Fig. 34. Deris itullata Forst. $f ; \times 11 \mathrm{~mm}$. Fulded wings 7 mm. head to tip of wing. New Forest, 15 vii. 1899. The commonest speries of the genus, closely allied to B. clarifis, which is distinguished by its larger size and black instead of yellow pubescence of ablomen, and in the female by its infumated wings. Harwool.

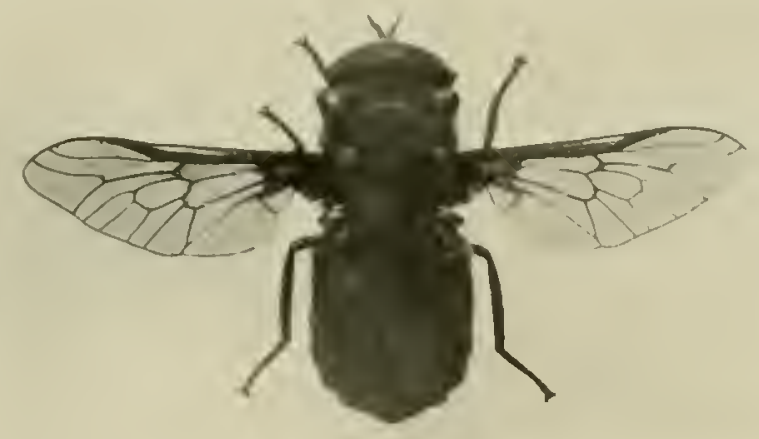

Fig. 35. Theriofledes mians Mgr. $1+\times 20$ mm. "Nut common in X. Forest" (Arlams). This sornup is split

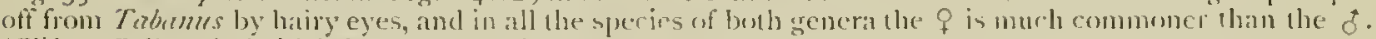
(Clifun College.) British Musem specimen. 


\section{BRACIIYCERA}

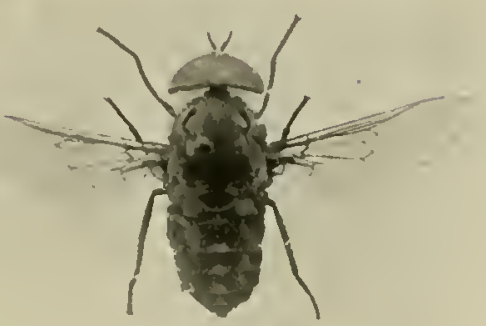

Fig. 36. 8.

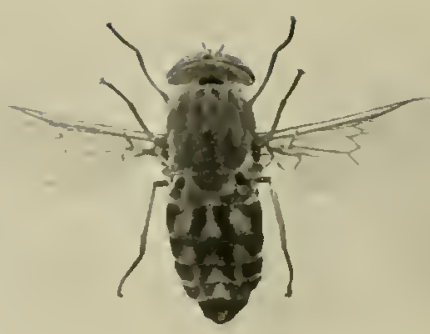

Fig. 37. + .

Fiuss. 36, 37. Tabanus autummalis L. \$ $16 \times 33 \mathrm{~mm}$., $\$ 19 \times 36 \mathrm{~mm}$. L'sually found at rest on thees and posts in and near woods, especially in late afternoons. Bites horses and cattle. Does not appear to bite human beings as vigorously as some others of this group. Habitat of the Hy and mouth parts here shown. Known popularly as Gid Flies or Breeze Fllies.

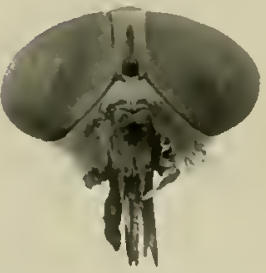

Fig. $3^{8}$. Mouth parts of Teturnus autumnulis.

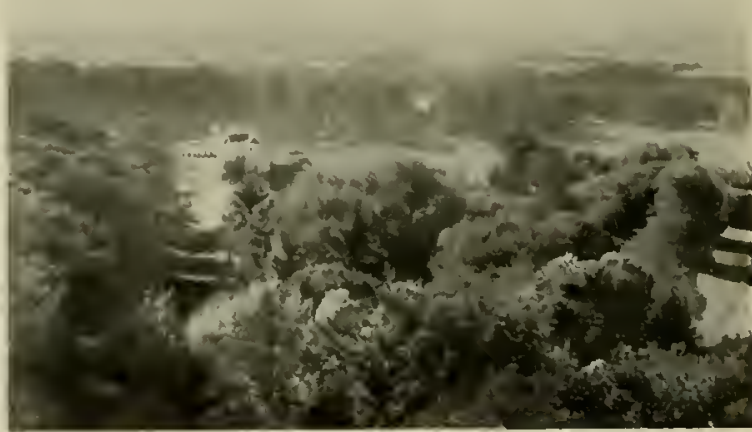

Fig. 39. Habitat of Tubunus autumnalis. (Thomas.)

Charborough Park, Dorset. 

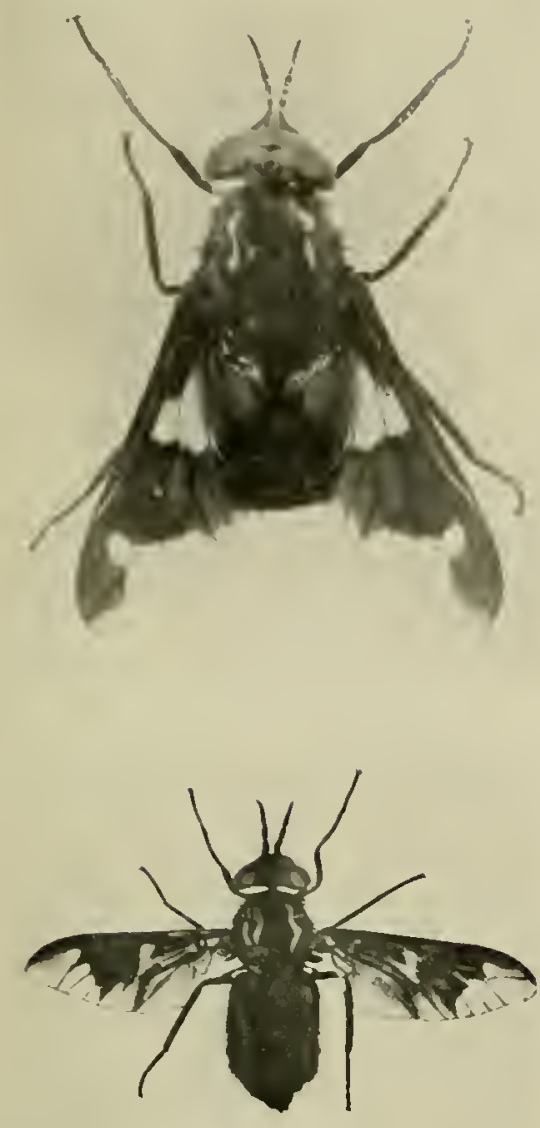

Fig. fl. ơ.

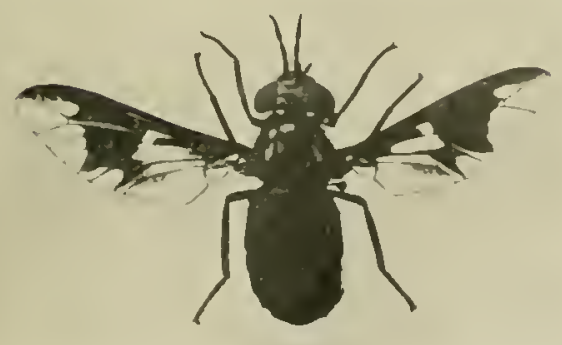

Fig. 42. ㅇ.
Fig. fo. Chryseps anicuticus $\mathrm{L}$. $q 9 \mathrm{~mm}$. from frons to tip of abdomen, $13 \mathrm{~mm}$. from frons to tip of wings. The male has abdomen entirely black, and is rarely taken. $q$ in swarms in damp weather in woods. Compare with Figs. $4 \mathrm{I}-43$. See Typical Flics, Figs. $43-48$.

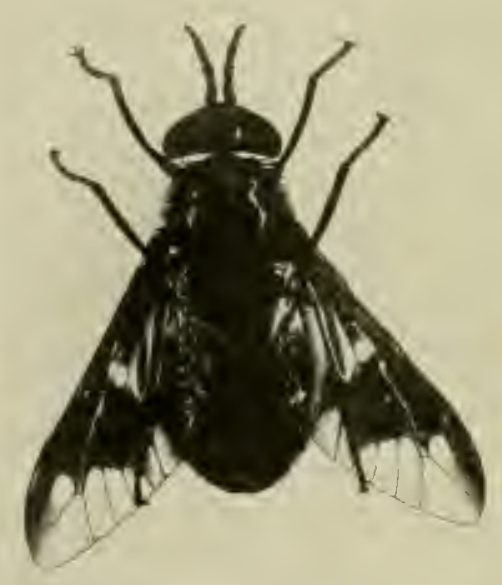

Fig. +3. + .

Figs $+1,+2,43$. Chrysops sepulcralis F. In these flics the ? vary in length from $6 \mathrm{~mm}$. to $8 \mathrm{~mm}$. In case of of solitaly or sparse, found on grass or rush in boys, and very swift in movement. In case of $q$ in swarms, and alighting on people. Abundant in certain marshy localities near Wareham, Dorset. On Morden Heath, in three days of two or three hours, 1 to were taken, all $q$. The ${ }^{t}$ were taken in twos or threes, July 1917, 1918, mainly in swamps. t $7 \times 15 \mathrm{~mm}$. In $\%$ spread of wings 13 to $16 \mathrm{~mm}$. 


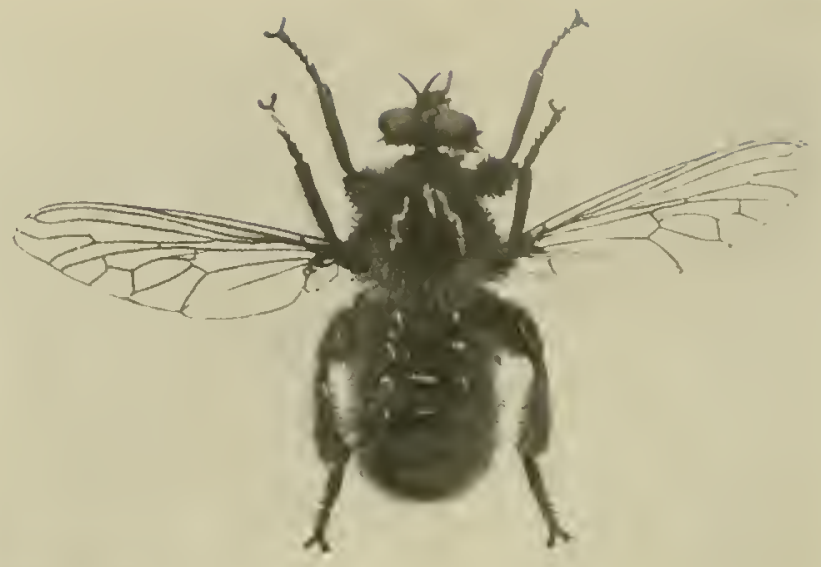

Fig. 4t. Lathria flater L. $\oint 17 \times 37 \mathrm{~mm}$. A rare species found at rest on logs in pine woods in Scotland and Nethy Bridge, end of June. Cp. of fig. 59 Typiucrl Flies. (P. Harwood.)

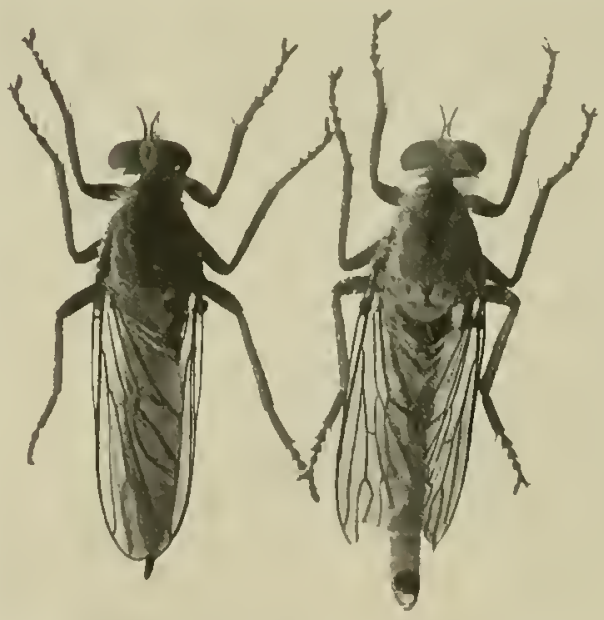

Fig. 45. Philonicus albicips $\mathrm{Ig}$. Figured at rest. of $16 \mathrm{~mm}$., $\$ 15 \mathrm{~mm}$. from frons to extrenity of abdomen. Southbourne, vii. IS. 


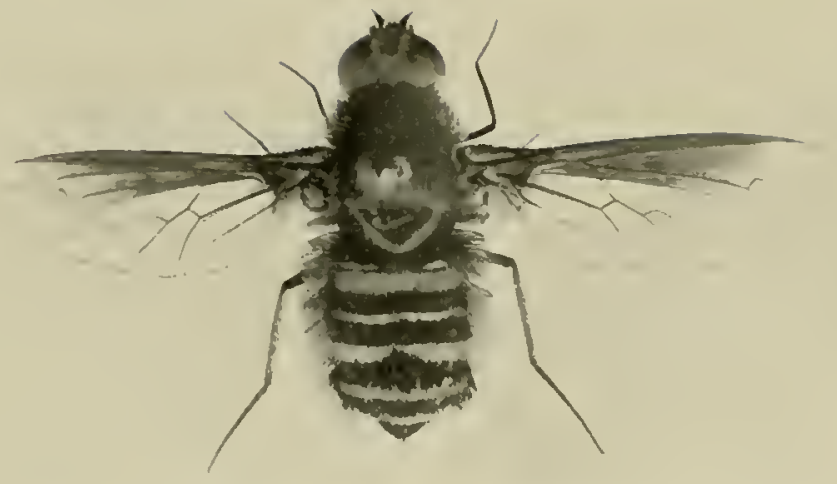

Fig. 46. . .

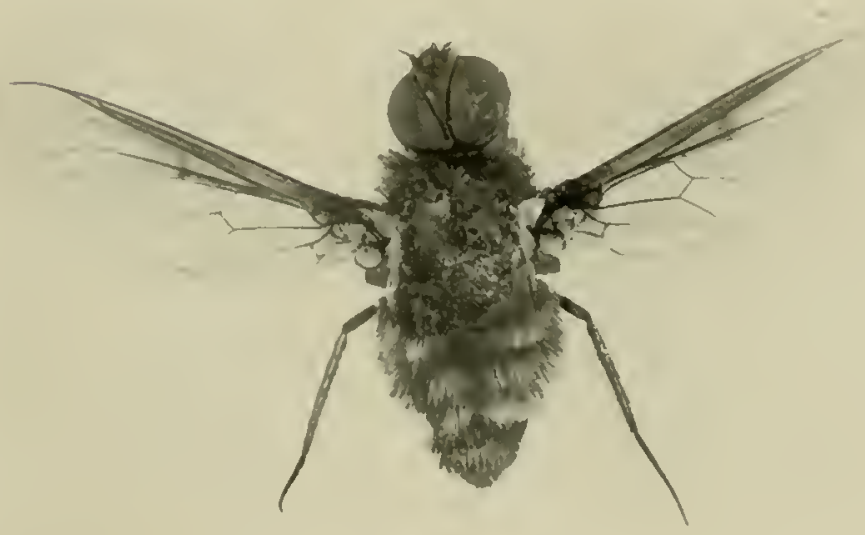

Fig. 47. ó.

Figs. 4 6. 47. Anthrat circumdutus. $\$ 11 \times 25 \mathrm{~mm}$. Taken in numbers on bare paths, Wareham Heath, by N. 1). F. l'earce and E. K. l'earce, August 1917, 1918. of taken by the late Reer. O. l'ickard-Cambridge (Bloxworth). Species parasitic in the nests of bees (Megachile and Anthophora), vide Westwood on Insects, vol. 11. P. 544. (Theobalkl.)

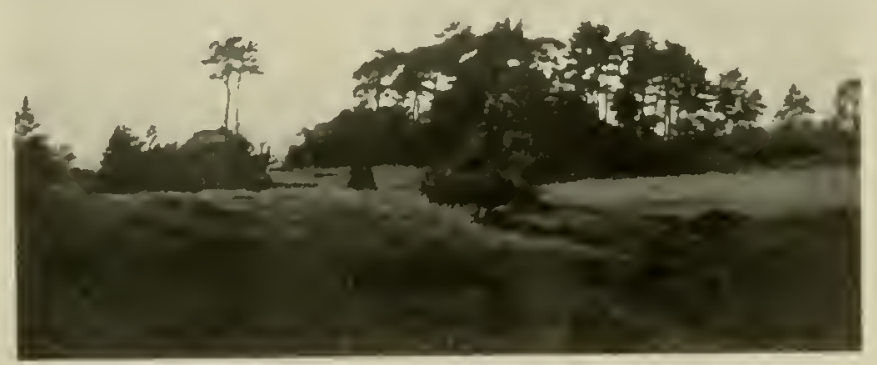

Fig. 48. Habitat of Anthret circumtutus, Wareham lleath. 

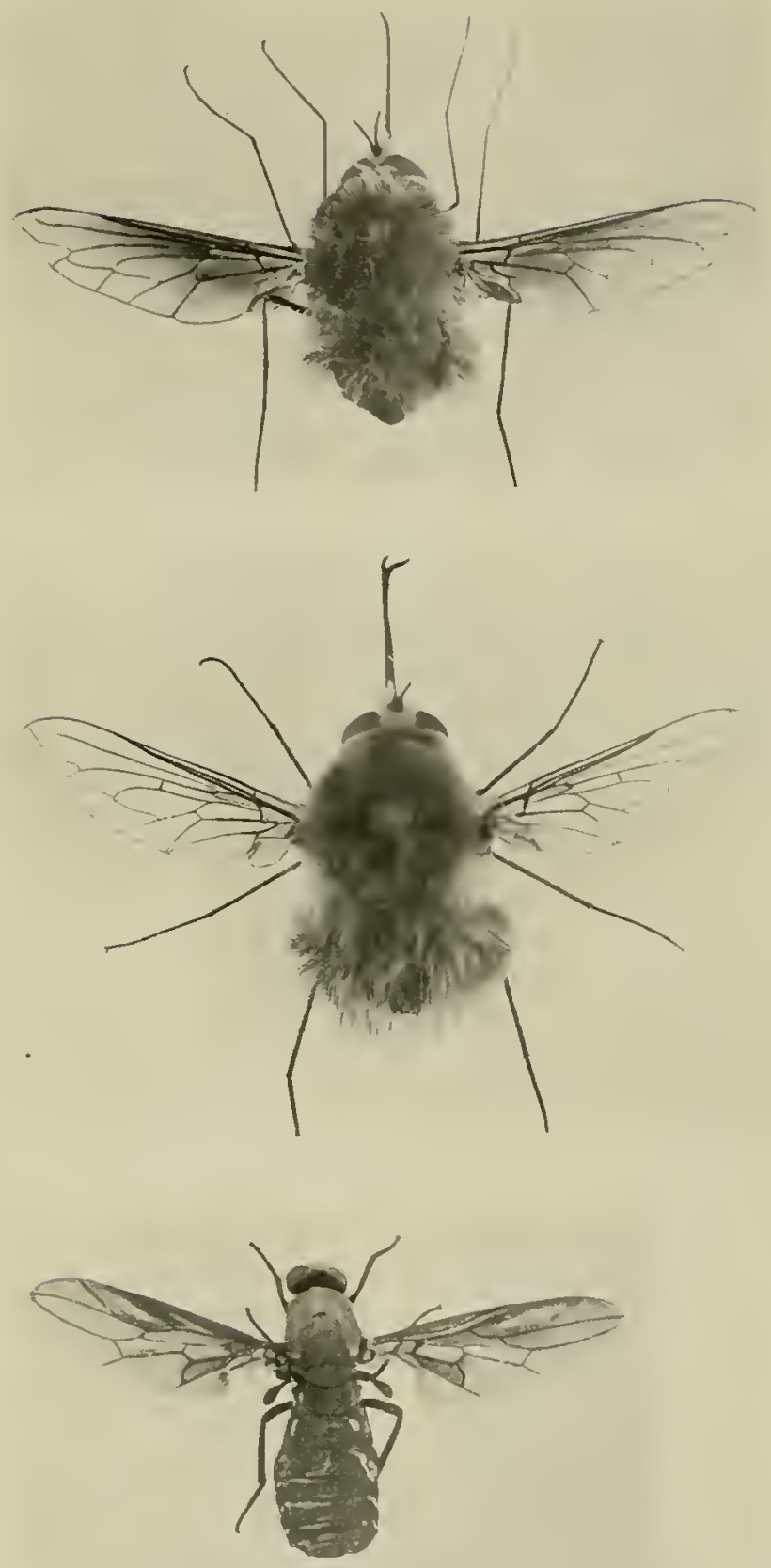

Fig. 51. Scenopinus fenestratis 1. $555 \times 11 \mathrm{~mm}$. On sindows end of summer and outhouses. (Adams, New Forest.) Larvae found in fungi and wood, and even under carpets. Carnivorous, long and slender, like the Therevidae. (Theobald.)
Figs. 40, 50. Bombylius miner L. o $8 \times 22 \mathrm{~mm}$. $\$ 9 \times 21 \mathrm{~mm}$. Wareham and Morden Heath, hosering over heather and ditches, probably coincident with a bee host; seen to be hunting banks, evidently for the object of ovipositing. Distinguished from cantescens by white pubescence on frons, in varying amount. (Cinlescens could not be found on Wareham Heath.) 


\section{ORTHORRHAPHA}

BRACHYCER.I
Empidae

Dolichopodidae

Lonchopteridae
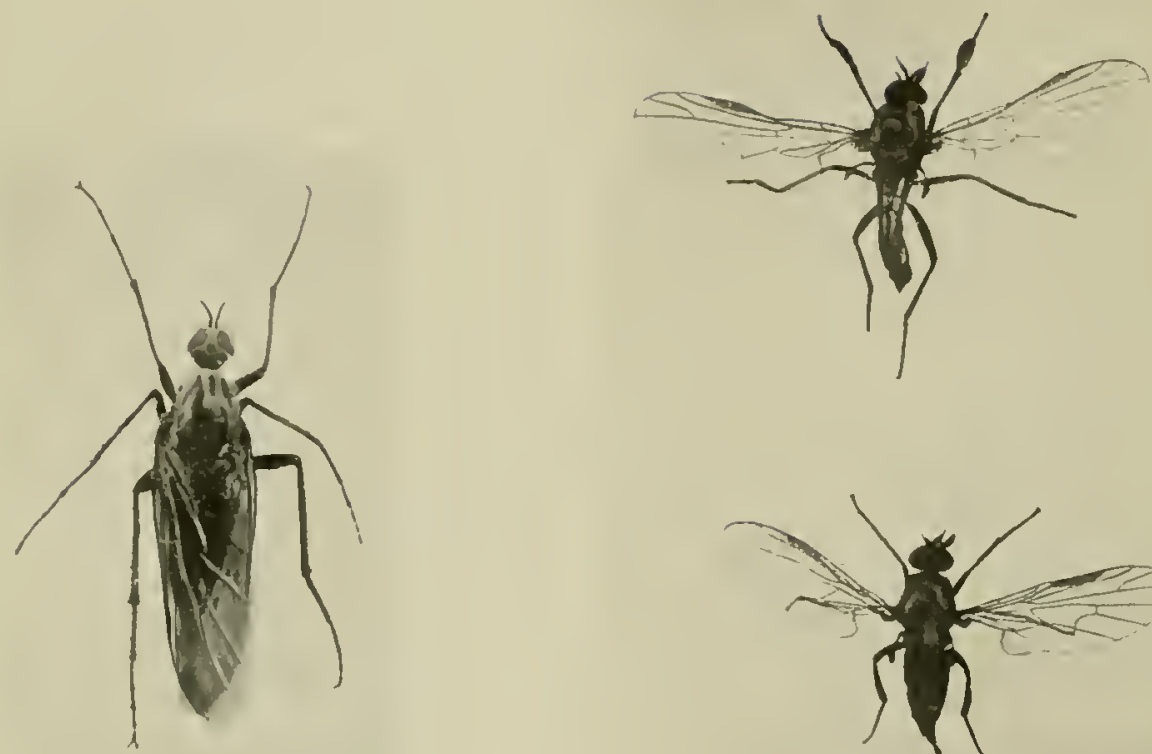

Fig. 53. Empis tessellata F. At rest, $12 \mathrm{~nm}$. to extremity of wing. Common on hawthorn blossom. Predatory insects, the imasines seizing other insects, from which they suck the juices. They are decidedly beneficial: for examples see Prof. Poulton's "Predacious Insects and their Prey" on Empidae and their Prey, Trans. Entomological Society of London, 1907.

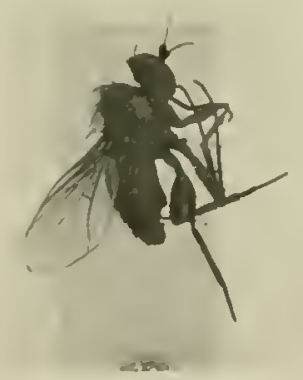

Fig. 55. Chrysolus neglectus II. of $3 \mathrm{~mm} .17$ vi. 1907, Studland. An iridescent green fly with pale buff-coloured legs. N. Forest. (Adams.)
Fig. 5t. Hilura munri F. of $+5 \times 11 \mathrm{~mm}$., $q+x$ $10,5 \mathrm{~mm}$. In swarms on Bourn Brook, Grantchester. (N. D. F. Pearce.) Intense dark brown to black throughout. of has forelegs dilated. The Hilarae feed on small insects, especially flies, but also Aphides. They assemble in swarms, and dance about in the air, especially over streams and pools. (Theobald.)

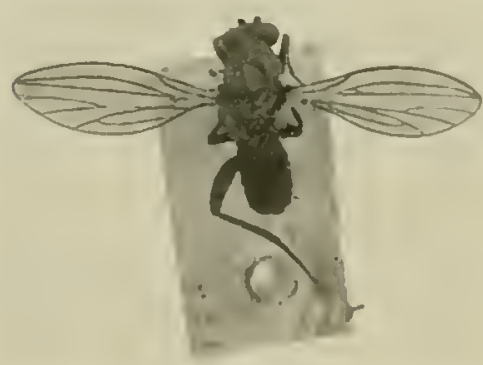

Fig. 56. T.onchoptiralute P\%. $93 \times 8 \mathrm{~mm}$. 24 vii. 1890, Harlesden. The of has different venation. $A$ brown $\mathrm{Ay}$, with legs of lighter hue. 

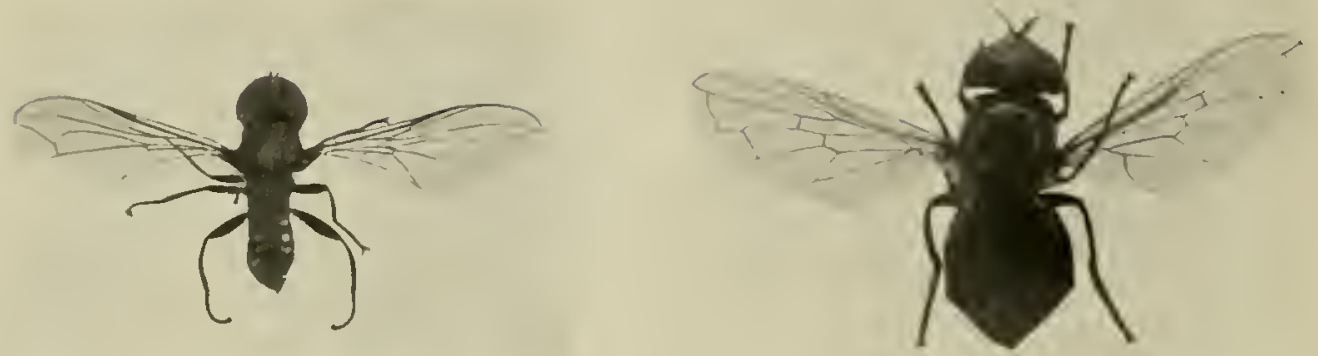

Fig. 57. Nipunculus furatus. $335 \times 10 \mathrm{~mm}$. Inhabits woods and fields, and often hovers in the atil.

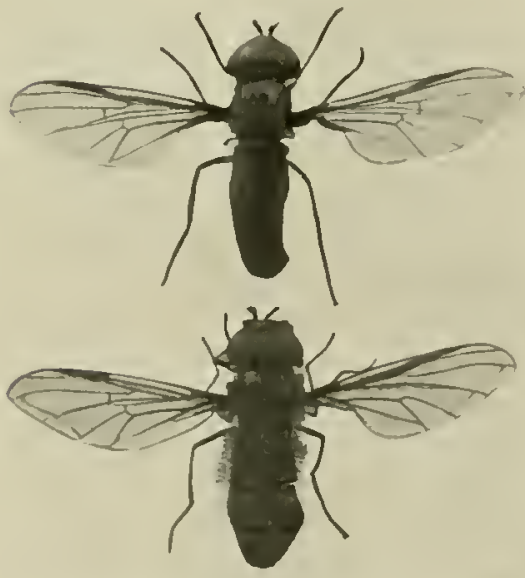

Fig. 58. Liogaster miterllina F. o $6 \times 11 \mathrm{~mm}$. Distinguished from Chrysogaster by the entirely metallic abdomen. In Chrysogaster the sides of the abdomen are shiny and the central area dull. Found on flowers of buttercup (Ramunculus bulbosus).

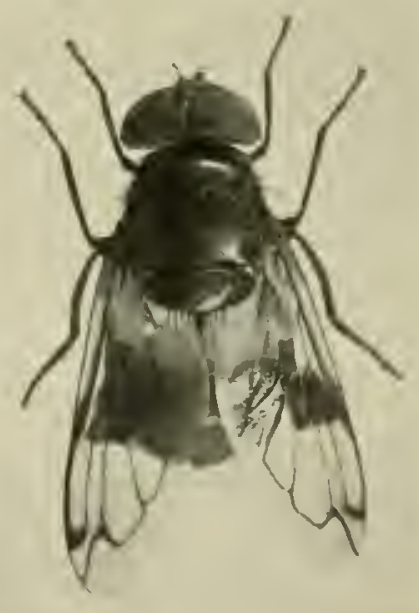

Fin. 59. Jelansyna quatrimaculata Verr. o $9 \times 18$ mm., $8 \times 18 \mathrm{~mm}$. The $q$ has no yellow markings. Always ratler scarce. lainswick.

Fig. 6o. Volucella pilluiens (Volucellinae) L. \&. At rest, 22 mm. from frons to extremity of abdumen. Sitid to act as scavenger in the nests of the larger Hymenoptera, or to be parasitic in their larvae, especially wasps. 


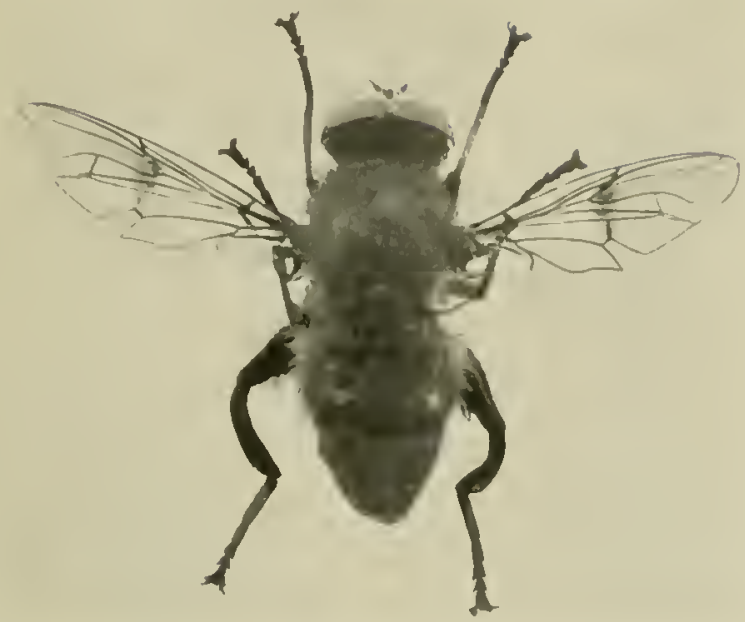

Fig.6r. 1/allotecimbiciformis (Eristalinae) Fln. $91+5 \times 25$ mn. On l'ortugal laurel or Dog Rose. New Forest (Adams), vi. 1894 and 1907. Thorax yellow pubescence. Body" dark brown; legs brown, shading to golden. Rare. Mlany in I 897 and 1900 . (Aclams.)
N. Forest.
Fig. 62. I'upa of J/eroton equestris (Eristalinae). $1205 \times 6 \mathrm{~mm}$. Narcissus bulb Hy. Very harmful to Daffodil, Lily and Tulip bullss.
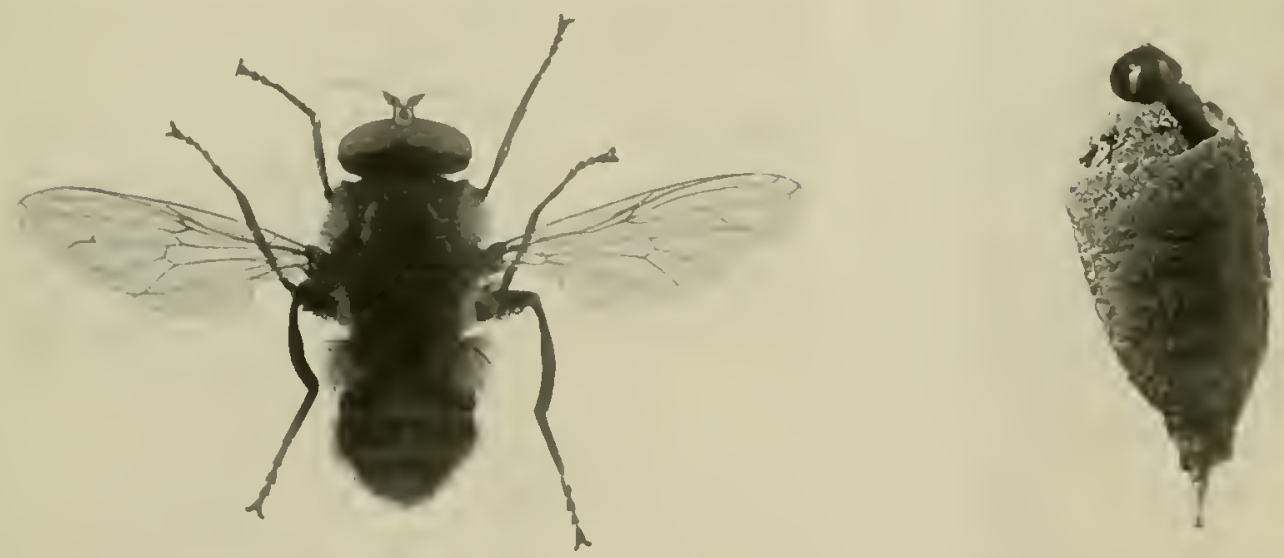

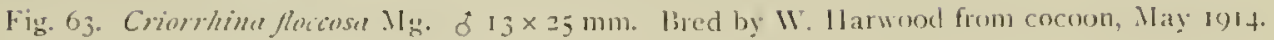
Fig. 6f. Cocoon, $7 \times 13$ mm., from whence emerged the specimen seen. Found at roul of loplat. 


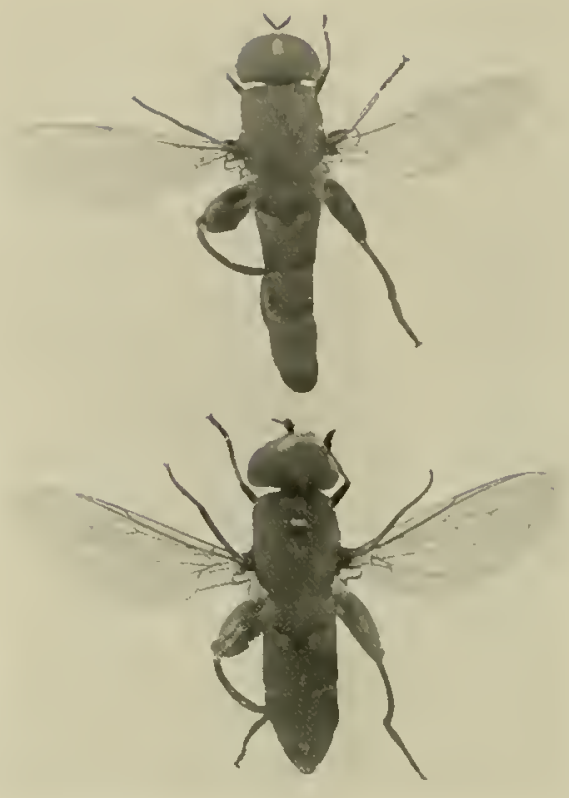

Fig. 65. Syritta pipins (Milesinae) L. $\$ 9 \times 14 \mathrm{~mm}$., of $8 \times 14 \mathrm{~mm}$. Abundant on flowers.

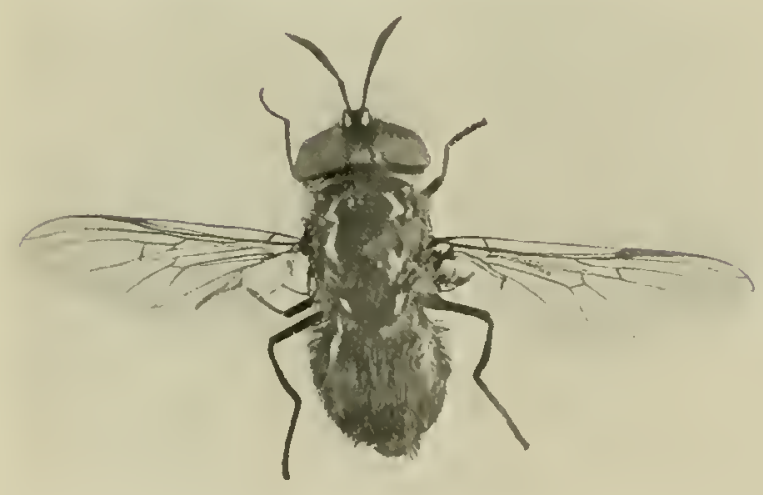

Fig. 60. Calliern anne (Chrysotoxinae) F. $+13 \times 26 \mathrm{~mm}$. New Forest. A gorgeously golden-coloured ty found on leaves of briar rose. Specimen found by Miss Chawner, vii. 190 I-2. Scarce. The senera, of which there are only two British species, is distinguished from Chrysotoxum by its terminal style. "Rare, but now communer. Six found on Rhododendron blussom vii. 1898 , at Rhinefields, New Forest; also on liramble and Vild Rose: July best month." (Adams.)
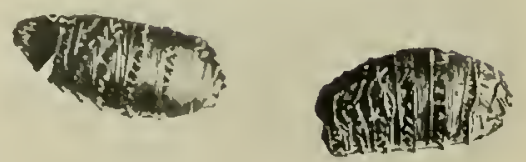

Fig. 67. Pupae of Gestrophilus iqui F. $15 \times 7.5 \mathrm{~mm}$. Brown to black in colour, found in meadows on and near horse droppings under the surface of grass. The horse bot larvae live in the horse's stonach. See Typical Flies, p. 37. 


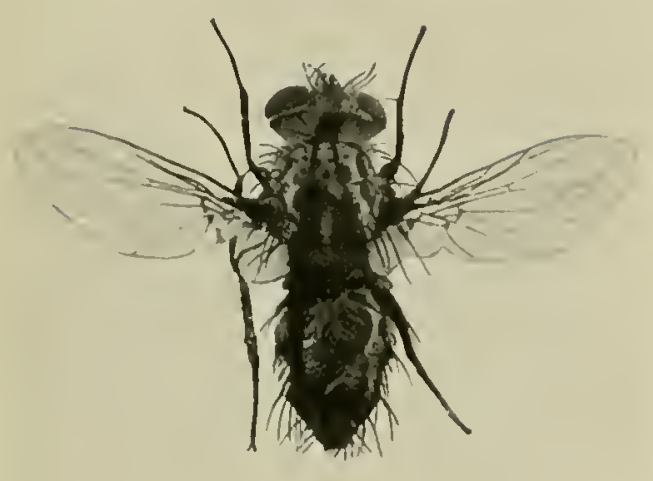

Fig. 68. Blepharidez rulgaris Fln. $S \times 1+\mathrm{mm}$. Destroys larvae of Picris rifori (white butter ly) and many Diurnia. The commonest Tachinid parasite on Lepidoptera, attacks many species, such as Thuessa urticat in great abiundance, Hesporia laneola, etc.; destroy's jo to So per cent. of summer broods perhaps. (Harwood.)

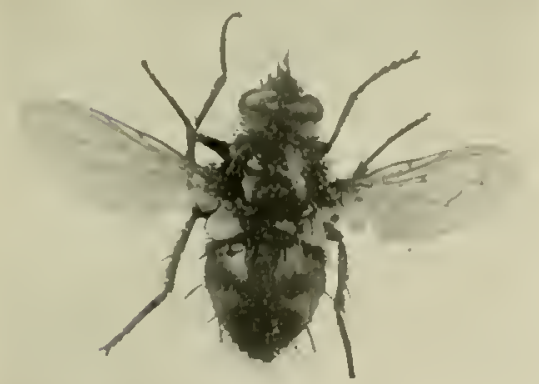

Figr. 70. Fabricia foror L. \& $13 \times 25 \mathrm{~mm}$. Horering over briar at Arne Conmun Roml, Dorset. Also found alsum rabbit burrows near Newbury, lierks, and sitting on sindy banks, Milllorook, Cornwall. Near Sallows.

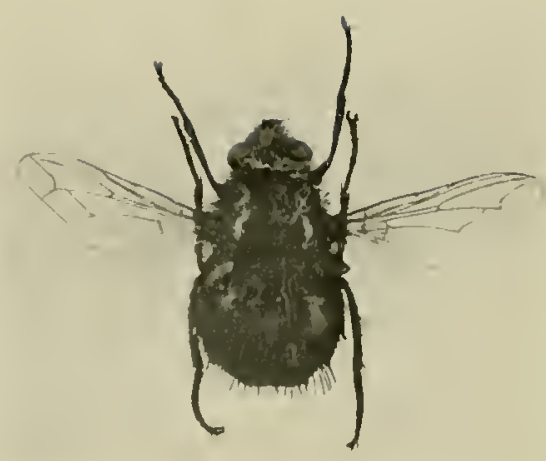

Fig. 69. Tachina Echinomyia) wossa L. $\$ 19 \times$ $37 \mathrm{~mm}$. Parasite on larve of Bombycid Muths. II ool, Dorset, vii. 19ı8.

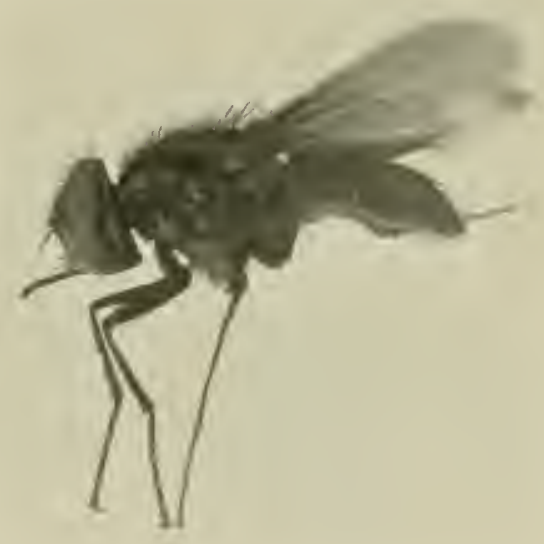

Fig. 71. Stomarys collithens L. ó 6 mum. froms to tip of abdomen. (Showing mouth parts.) Hurtfu] to horses, and biting peosple from its resting-pl.tce on windows in autumn. This species, which it gley in colour with black spottings, is the commones buing fly amony the Muscilae. It has often mate horses uncontrollable, and cattle are dliven wild ly it. "It can be distinguished by its habit of sittiny. sideways." (Harwood. 


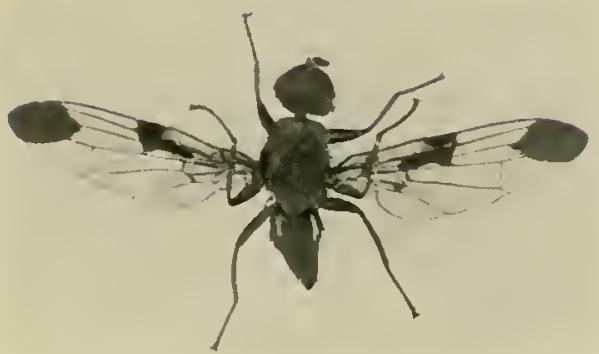

Fig. 72. (Nyatacinate) Spilosatster Zoi: of $4 \times 10 \mathrm{~mm}$. Thorax and head paler brown than the abdomen, which is rlark. latrvae found in decaying animal and regetable matter. l'ossibly like 1 . uliginosus in rotten wood.

Colchester.

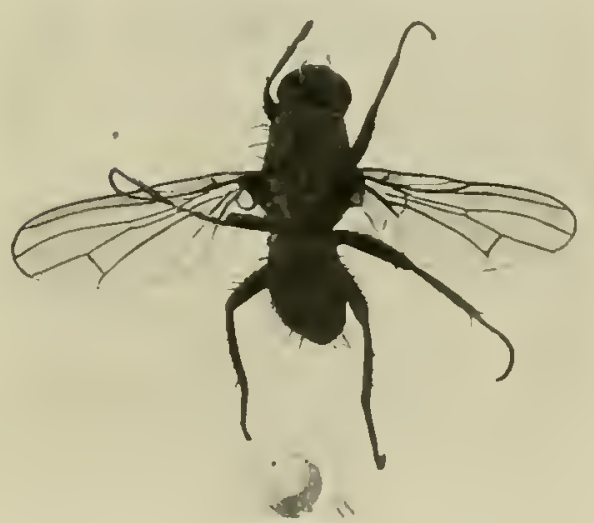

Fig. 7t. (Cacuosince ) Fucellin fucorum Fln. $5 \times 18$ mm. I 8 viii. rgoo on cuast sands above hish water. Found along the sea shore generally, here and in America. A pale brown fly of uniform colouring, with bristles on thorax and legs and extremity of ahdomen. "Christchurch Bay:" (Adams.)
Fig. 73. (Anthomyimu) I'horliti ceptorum Meacle. of 8 mm. o $9 \mathrm{~mm}$. fruns to tip of wing. The onion fy. Onions should be lifted and the larvae destroyed. If pulled, the yrubs remain in the soil and spread to sound bulbs; a dressing of soot is recommended as preventative to attack.

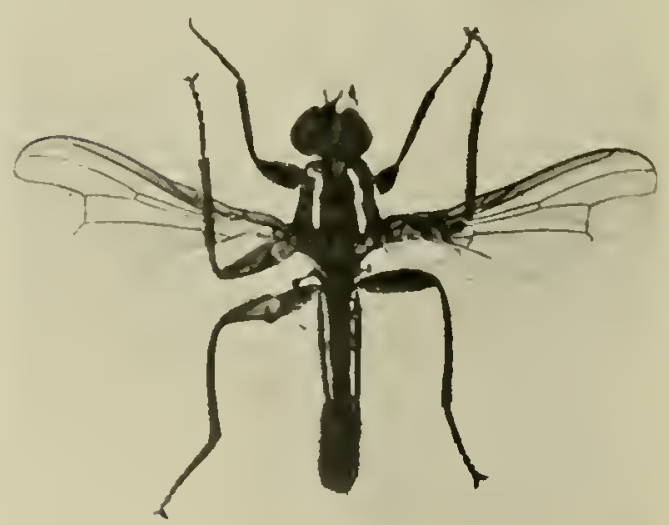

Fig. 75. Cordylum illate $11 \mathrm{~g}$. o $105 \times 16 \mathrm{~mm}$. Near pivers and amongst grass. Summer and autumn common. 


\section{Proroscidea}

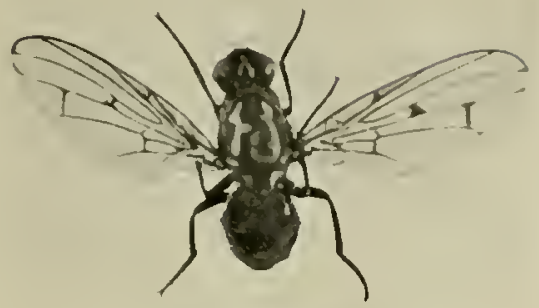

Fig. 76. Vemmilenu anilis Fln. $99 \times 19$ mm. New Forest. (Adams.) Near damp places in summer.

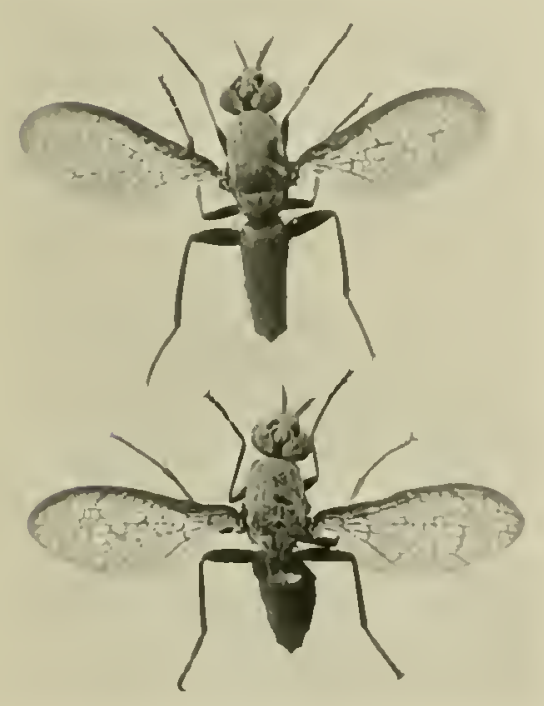

Fig. 78. Limmin murgillete $\mathrm{F}$ o $7 \times 13$ mun., $96 \times 1+m m$. Found by sweeping grass neat the East Coast, St Osyth. Also from inland on the Roman Roarl, neal Cambridue. viii. 19I8. (Halrwioll.

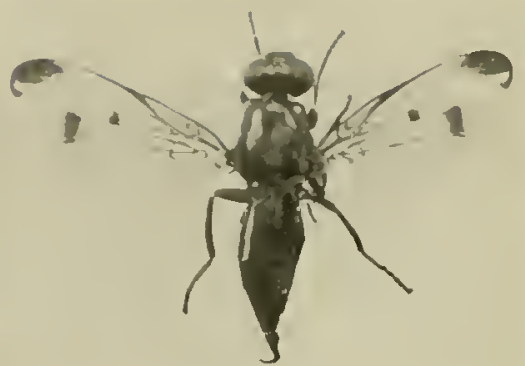

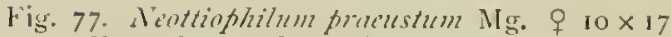
min. From larvate found in fincles' nests, from May 20 to end of Jume. New Forest. (Adams.) Golden brown abdomen, banded darker shade. Spots on wings still darker brown. Rate.

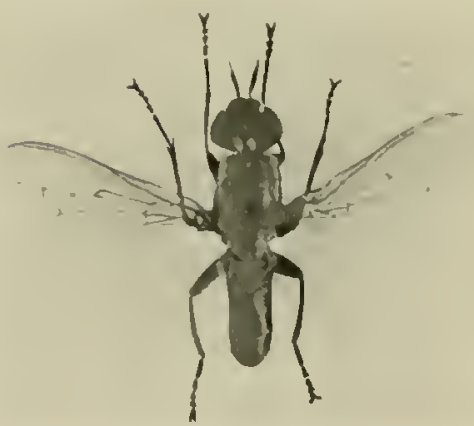

Fig. 79. L̈lgiźn albised Sicop. of $7 \times 1+\mathrm{mm}$. Sometimes abumbant amongst rush and coaldse grass. 


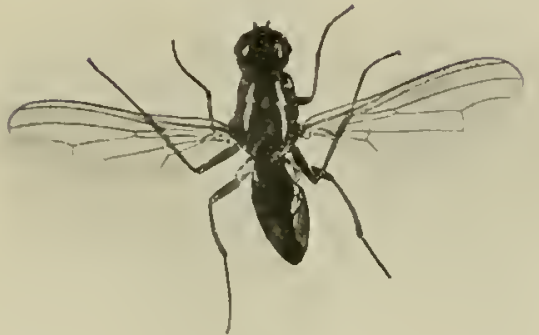

Fig. 8o. Psila fimetarin L. \& $8 \times 17 \mathrm{~mm}$. Along hedgerows. Compare with the carrot fly, Psilu nigniormis.

Colchester.

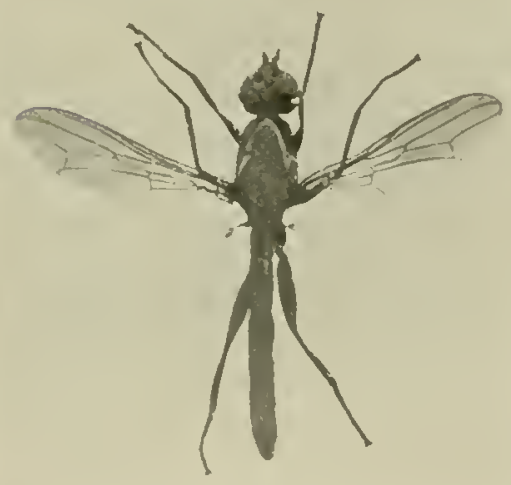

Fig. 82. Lissu lorocrine Filn. $\mathrm{S} \times 10 \mathrm{~mm}$. Taken on Rhamnus, New Forest, 190s. Perfectly smooth, dark brown body; legs brighter red brown.
Fig. 81. Loxucra aristate $\mathrm{P}_{2}$. $\quad 10 \times 14 \mathrm{~mm}$. Common on beating whitethorn and on other trees near water. Sudbury, Suffolk. A dark brown fly; thorax and legs bright red brown. Smooth and devoid of hairs or bristles.

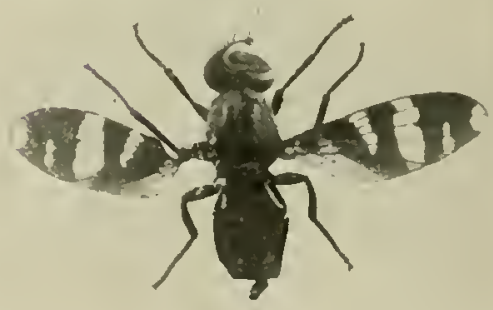

Fig. 83. (Orhlintie) Priropitedria frondescentiae $\mathrm{L}$. $+4 \times 8 \mathrm{~mm}$. Found in damp places on the marshes by sweeping. Wicken Fen. (N. D. F. P.) Body black, wings banded, intense dark brown. 


\section{Prolioscidea}

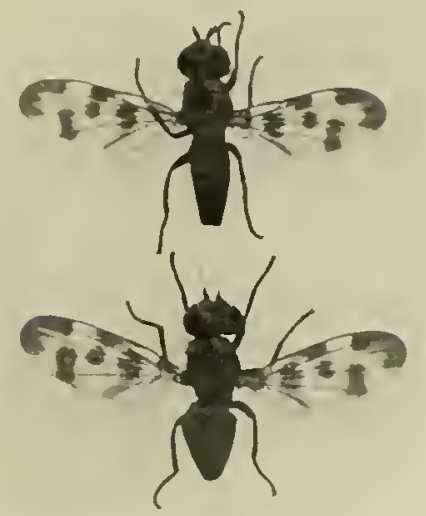

Fig. $S_{4}$. (Ordulinat) Ceroxys fichus $M g . \delta+\times 8$ mm., $q+\times 9 \mathrm{~mm}$. Essex marslies; common in swecping grass and sedure on sea coast marslies. (St Osyth, Essex.) Lody grey brown, legs of same colour, darker wing spots.

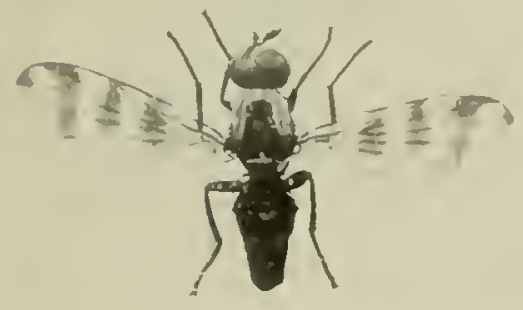

Fig. 86. Ortalinate) Anncampla mrtiate 1. $q 6 x$ $13 \mathrm{~mm}$. (I) Eritl . Marshes, roof, and in similal localities, but genually scitce. (Andrews.l Brown stripes on wingrs, exceedingly dark brown boxly.
Fig. 85. Orfalinue) Ceroxys irassitenmis F. o $8 x$ $17 \mathrm{~mm}$. In numbers at Aviemore: and river mouth of Thanes Estuary. ("I. F. King.) A dull light brown fly. Wing spots and lews of brighter brown hue.
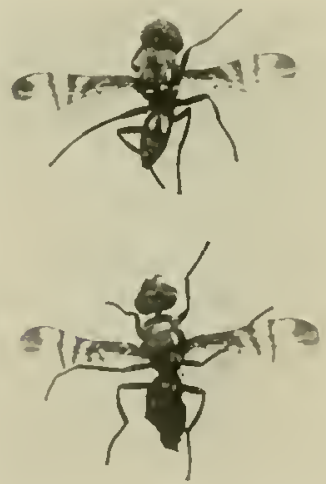

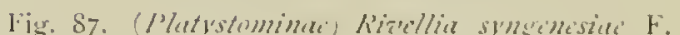
$92 \times 6 \mathrm{~mm}$, of $2 \times 5 \mathrm{~mm}$. Found by sweeping in meadows. 22 vi. 180 ). (Idams.) A blue-black th; brown mottled wings. 


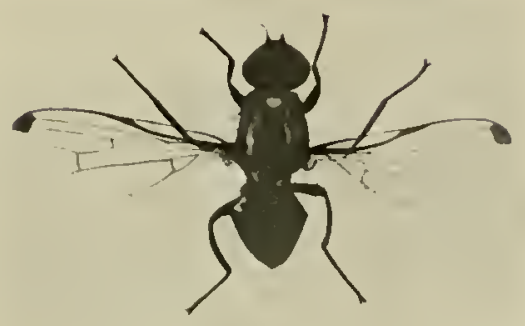

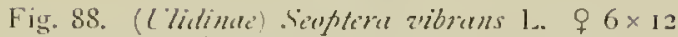
mm. Common in gardens; runs down leaves rapidly vibrating its wings, hence the name. A black $H y$, with black spots on wings.

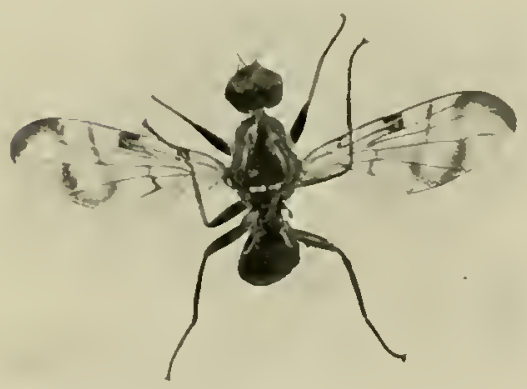

Fig. go. Acidia cognata 11 . $\$ 6 \times 14$ mm. A golden brown fly throughout, with exceptions of dark brown wing markings. "Sway, New Forest." (Adams.)
Fig. Sy. Acima rotundisentris filn. $4 \times 10 \mathrm{~mm}$. Bred from liurdock by Ml King and by Ml Adams. New Forest. A very handsome dark brown $H_{y}$, mottled dark brown wings and bufflegs. Found also, Matley liog, New Furest, on Anerelica sylatuticu.

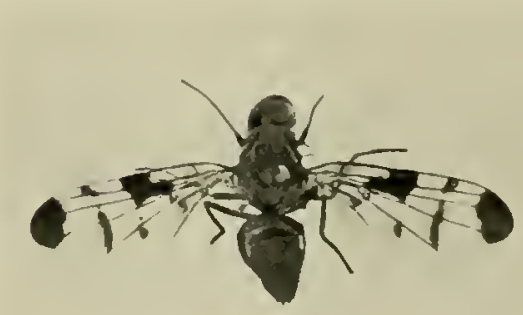

Fig. 91. Spilographa Zoë Mg. of $+\times 10 \mathrm{~mm}$. A pale brown fly with pale leys and darker wing spots. New Forest. (Adams.) 


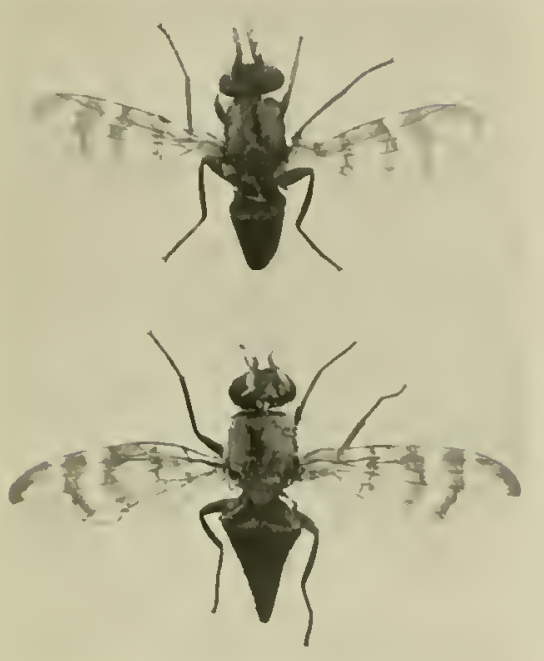

Fig. 92. Tigpede immutel o $5 \times 12$ mm., o $8 \times$ It mon. Red brow in throughout, wings with pater bands.

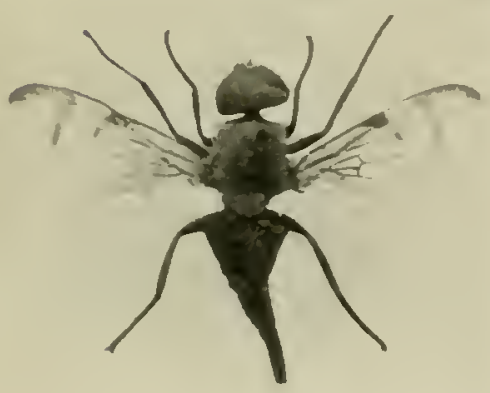

Fig. 94. Crophara stylutu F. $97 \times 11 \mathrm{~mm}$. Among Scotch thistles (Onopordum acunthium). A dark brown fly, wing bands and legs bright red brown. Galls the Horal receptacle of Cirsimm lemcolutum forming a hard, many-chamlsered gall. ("heobakl.)
Fig. 93. Urophora solstitialis 1. $q+m$ m. to end of uripositor, $10 \mathrm{~mm}$. arross wings. A tly with dark brown abdomen, but wing bands, leus amd thom brighter red brown.

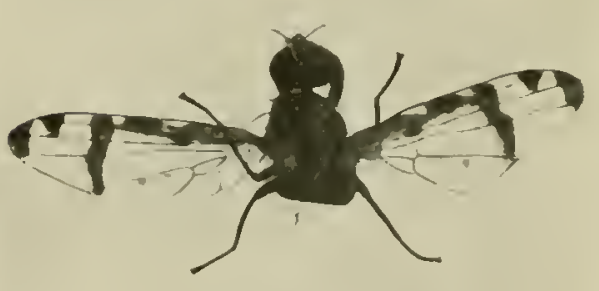

Higs. 95. Sphenella merginate Fln. 9 mm. across wings. A pale brown ty, wing markings pale to dark shade of brown. 


\section{PROBOSCIDEA}
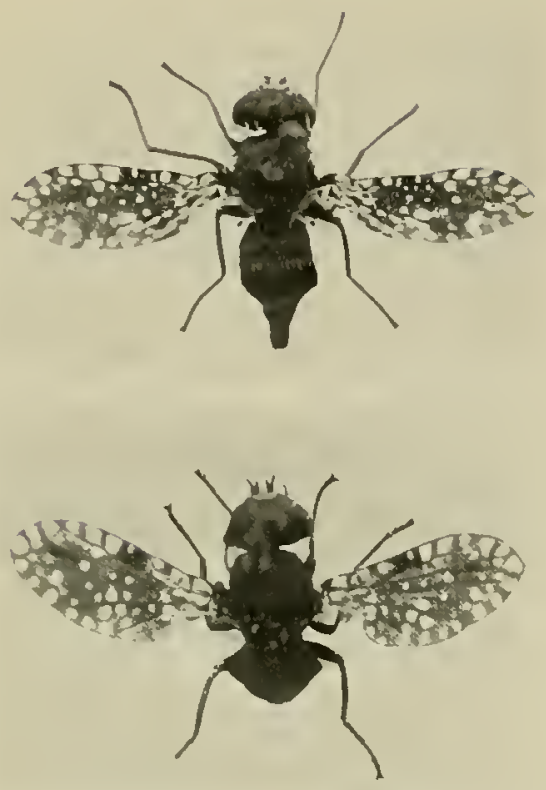

Fig. 96. Carphotrichu guthuhuis Mg. $\delta 4 \times 8 \mathrm{~mm}$., $4.5 \times 9 \mathrm{~mm}$. Found by sweeping among Galium rerum at Copford, Essex. "New Forest, but not common." (Adams.) A dark brown fly, legs and wing markings bright red brown.

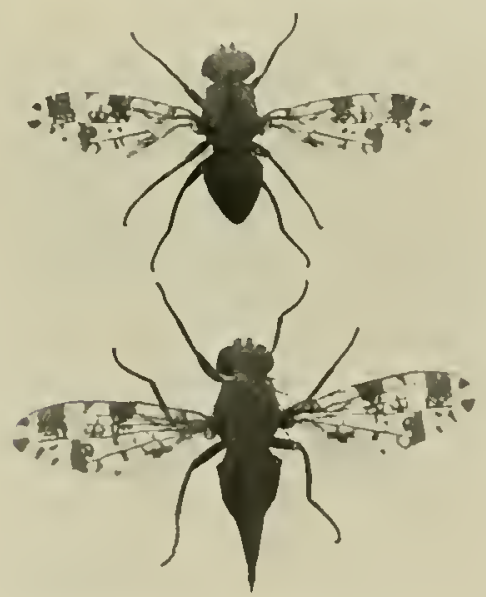

Fig. ys. Teplutils leysicumi L. ô $4 \times 10 \mathrm{~mm}$, $96 \times 11.5 \mathrm{~mm}$. Taken in a patch of thistles by $P$. Harwood, lishop's Stortford. A dull brown fly', legs and wing markings of lighter hue.

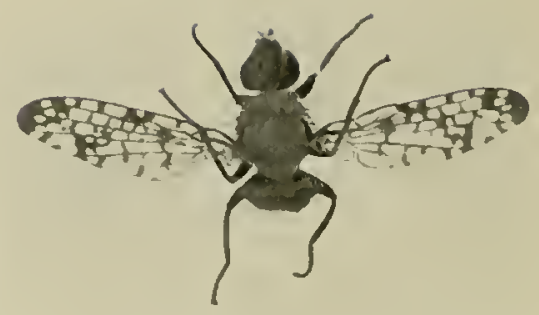

Fig. 97. Tephritis flumbginis Hal. of $5 \times 9^{\circ} 5 \mathrm{~mm}$. Taken by sweeping amongst $A$ ster Tripolium. Clacton-on-Sea, viii. I9II. (Harwood.) (ialls the inflorescence of Aster Tripolium. (Theobild.) A dull brown fy, legs and wing markings slightly brighter in tint.

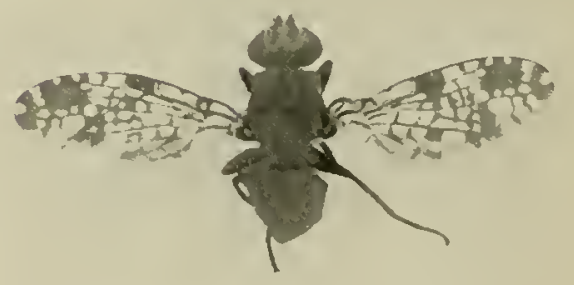

Figr. 99. Tephrilis tespertimu Lw. of $4 \times 8 \mathrm{~mm}$. New Forest. Red brown mottled wings, with body of lighter grey brown shade. Larvac feed in heads of Compositat: "New Forest." (Adams.) 


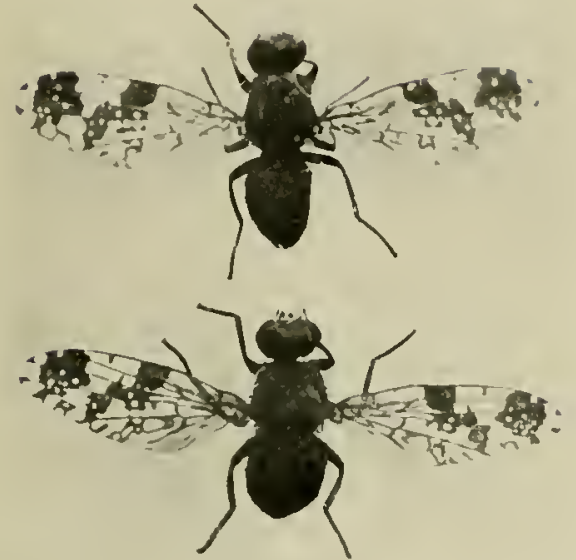

Fig. 100. Teplarilis bardanue Schrk. \& $45 \times 11$ mm., $5 \times 125$ mm. From heads of burdock (Aritiml Letp pis). A dull brown ty, with dark wing narkings, but legs and extremity of abdomen of bright red brown. "New Forest." (Adans.) Stanway, Essex.

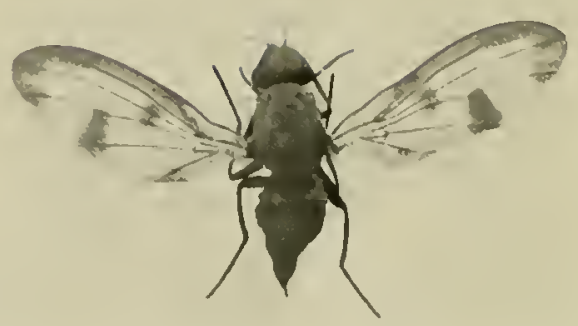

Fig. 101. Palloptere ambellatarum F. $4 \times 10^{\circ} 5 \mathrm{~mm}$. A sull brown $\mathrm{fly}$, with slightly infumated wings and brown spots. Abdomen yellow brown.

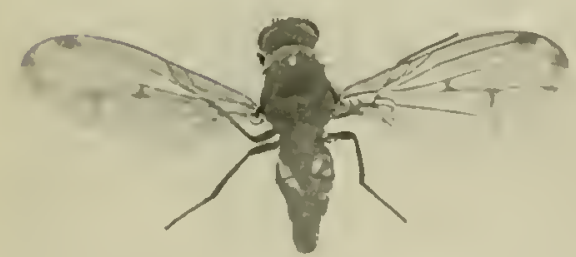

Fig. 102. Pilloptera decimpunctuter. $\delta+\times 10$ mm. Figs. 101 and 102 are uncommon forms, found by Mr Adams beating in the New Forest uccasionally, 28 vij. 1908. A light brown $\mathrm{Aly}$, winer spots and leg's of same tint.
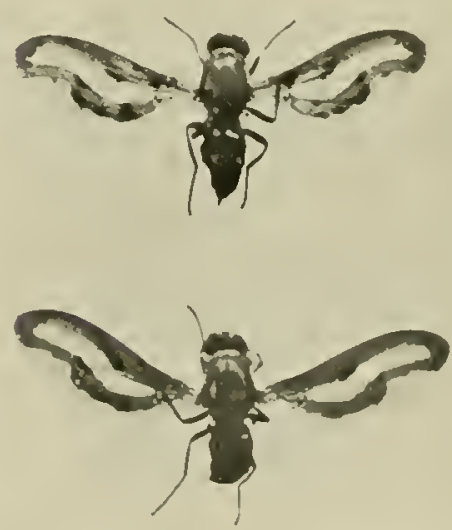

Fig. 103. Tononcura mulicbris Harr. of $3.5 \times 7 \mathrm{~mm}$, $935 \times 10$ mm. On windows at Kempston, lioumemouth West, viii. 1917. Bright red brown $\mathrm{Ay}$, with white spaces on wings. P'robably hew in from Ceanothus outside. 
CYCLORRHAPHA

Proboscilea

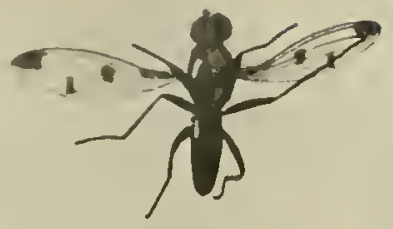

Fig. 104. Batioptere trifunctata Fin. o $3 \times 7 \mathrm{~mm}$. New Forest, 26 viii. 1006. A dark brown fly, legs and wing spots of darker red brown.

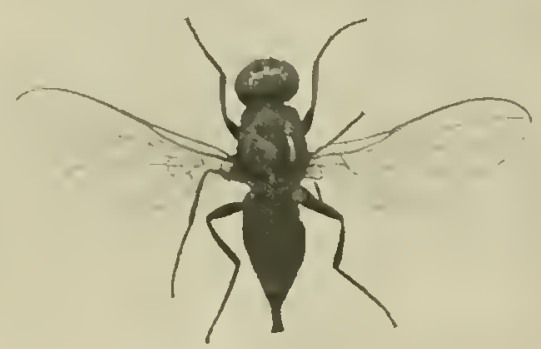

Fig. 106 . l'ophilu cersei L. $6 \times 19 \mathrm{~mm}$. Found at a London Club. (Adams.) 25 vii. 1898 . Larvae in cheese; cheese magrut. Kept off fresh cheese by means of muslin shelds. A dark brown smooth $A$ y; with a partiality for cheese.

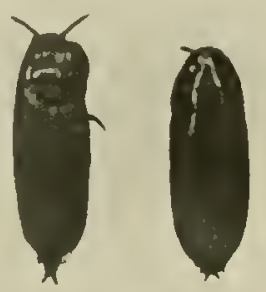

Fig. 108. l'upa of l)rosophilu funchris. (liritish Musem specimen.)
Opomyzidae Piophilidae Drosophilidae
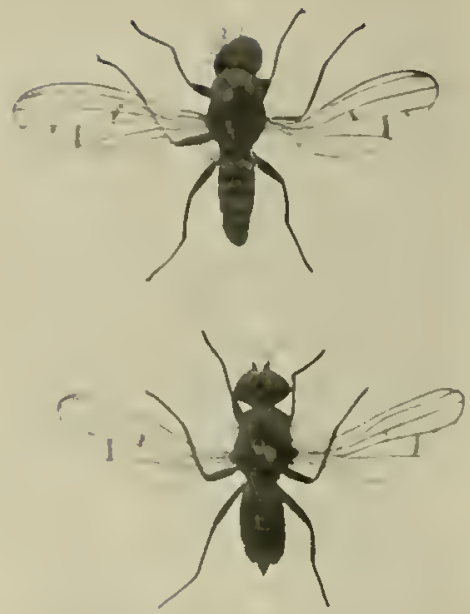

Fig. 105. (1pomyat flomem F. क $3.5 \times 8$ mm., of $3 \times$ $7 \mathrm{~mm}$. Found by swceping srasses, bishop's Stortford. l'ale golden brown throughout, darker shade of wing spot.

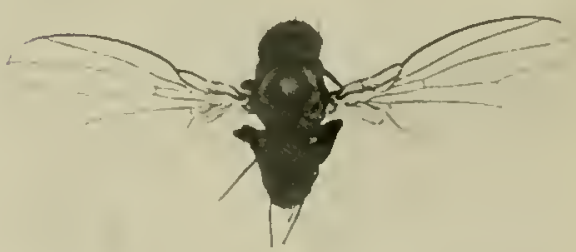

Fig. 107. Drosophila festestermm Fln. $3 \times 9 \mathrm{~mm}$. On windows, February and March, Grantchester. (N. D. F. P.) The larrate of the Jrosophilidae feed un plants, nak apples, fungi, cheese. Some mine the leaves of plants. Drosophila funebris is often called the soft cheese fly. D. colluris feeds on the matter adhering to beer and wine corks. D. melemegaster attacks grapes. ("Theobald.) 


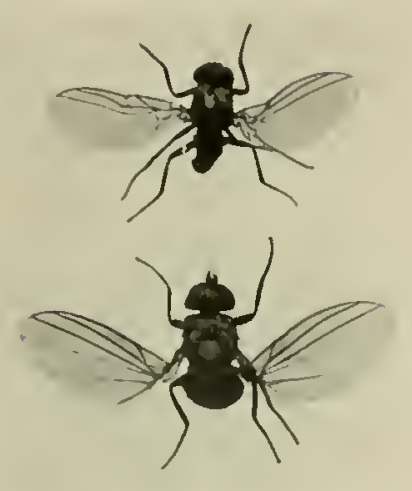

Fig. 100. Chromatomia ilicis Curt. $\delta 2 \times 6 \mathrm{~mm}$, \$ $2.5 \times 7 \mathrm{~mm}$. Emerges from Holly Leaves. The pupae are concealed in varicoloured blotches. foung leaves attacked by the fly are very disfiguring to ornamental hollies. Kempston, Bournemouth West, vi. 1016.

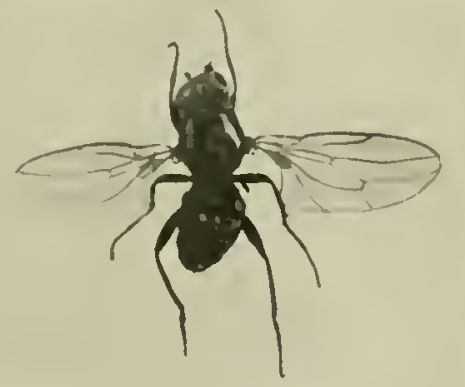

Fig. 11. Limosiun pumilio Mg. $3 \times 7 \mathrm{~mm}$. Fels. and March. Fountain, Grantchester. (N. I). F. IP.) A dark brown fly throughout. Injurious to Rhubarb routs. (Theobald.)
Fig. 110. Borborus iquinus Fln. $q+5 \times 10$ mm. New Forest. (Adams.) A dark brown $\mathrm{fly}$, portions of legs of brighter brown hue. The larvate feed in decaying substances. (Theobald.)
Fig. 112. Phora opuca Mg. $2 \times 6 \mathrm{~mm}$. Mareh and April, near fountain and windows at Grantehester, 1010. Latrite of the Phoridac are cylindrical, thimer in front than behind, and live in dead insects and snitils and decaying vegetable matter. (Theobald.) 
In the Eproboscidea the ovum hatches within the body of the parent, and is deposited as a larva and pupates rapidly. (See Cambridge Nat. Hist. vol. vi. p. 517 , and british Bloodsucking Flics, E. E. Austen, p. 62, family Hippoboscidae.)
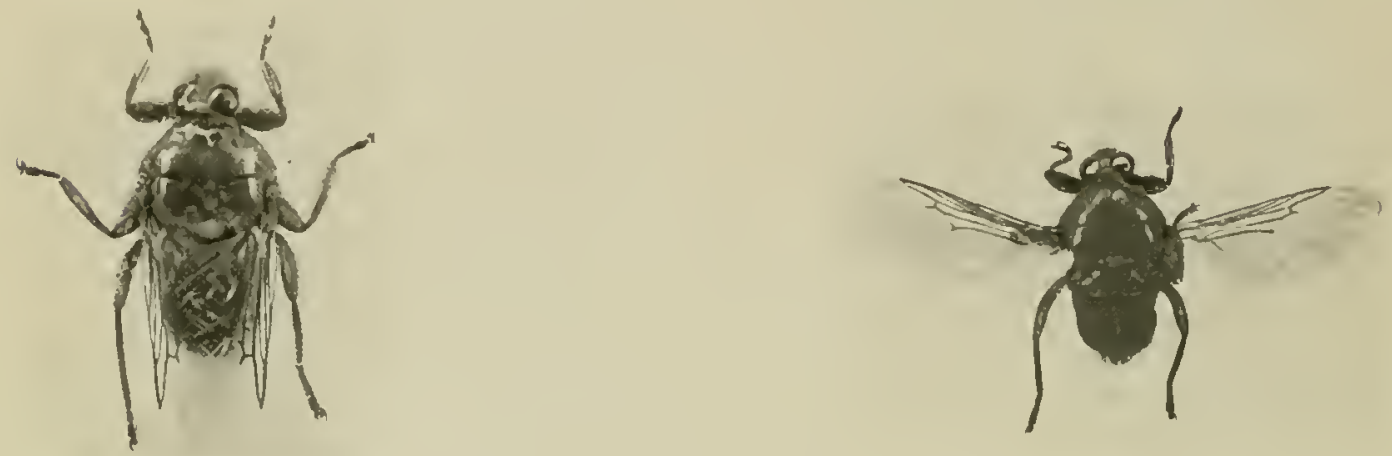

Figs. 113,114 . Hippobosa equina L. $7 \times 18 \mathrm{~mm}$. New Forest, 19 ix. 1915. (Adams.) These flies are found on the Forest ponies. Hurses not used to them, when attacked, become unmanageable.

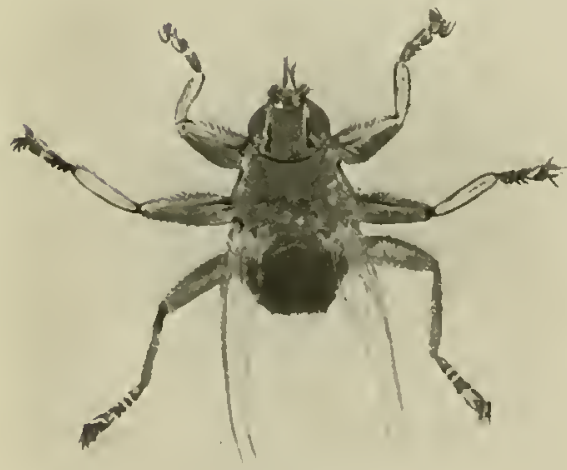

t.

Figs. I 15, 16. Stenoftery himmlimis 1. o $3 \mathrm{~mm}, 5 \mathrm{~mm}$. Found as spherical dark brown puparia in the nests of Matins and Swallows, Hauxton Mill. (N. D. F. Pearce.) Bred out Sept.-Oct. I9I7. A pale brown fly throughout. 
CYCLORRHAPHA

EPROLOSCIDEA

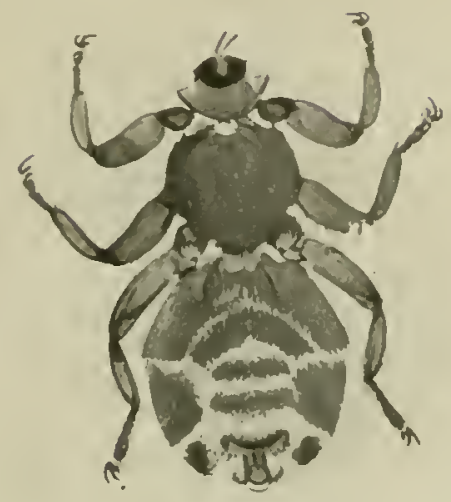

Fis. 117. Lifoplina cerri L. $q 6 \mathrm{~mm}$. Palrasite of Cipreolus cupreer. Micro-slide of Rothschild collection, Tring. (By permission.)

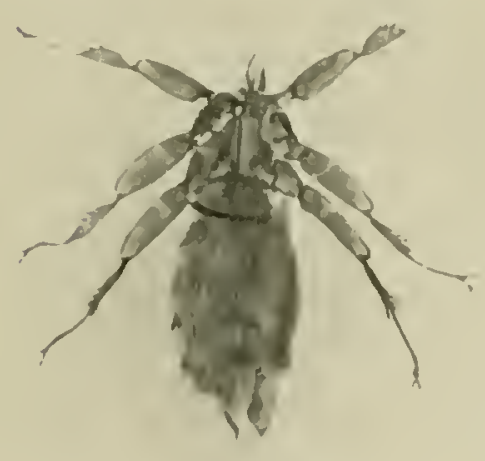

Fig. I 19. Nycteribin (Listrupudies) pediculurin Láltreille. \& ventral view. From lispertilio duuber. loni. Wells Cathedral. Somerset. vi. $1006.2 \cdot 5 \mathrm{~mm}$. From micro-slide, kuthschild collection, l'ring. (By. permission.)

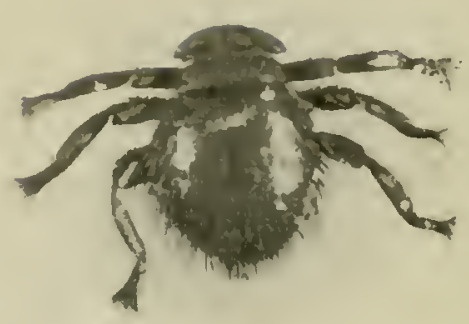

Fig. I 8 . Fromla atea Nitz. Found on bees at Grantchester by N. D. F. P'earce. (Iff a worker of Afir millifica. vii. 1915. This is one of the wellknown Hive liee Parasites.

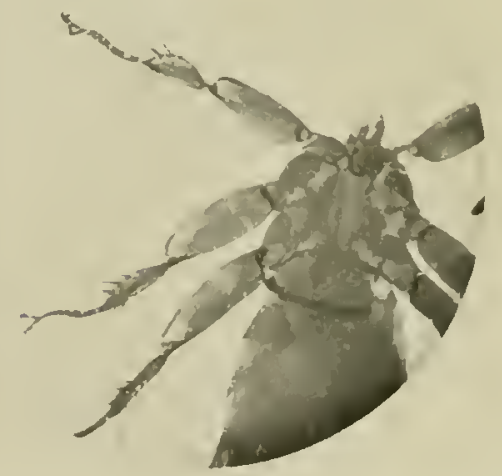

Fig. 120. Legs of Victiribit perticularia enlarged. 


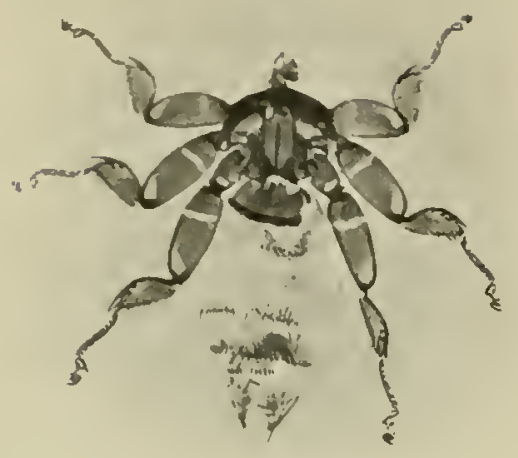

Fig. 121. Nycteribia (Listropodia) pedicularin Latr. var. blasii (Kolenati) Scott. $\oint_{2} \cdot 2 \mathrm{~mm}$. ventral view. From Vespertilio dubentoni, Henley-onThanes. 14 ii. Igo6. From micro-slide, Rothschild collection, Tring. (By permission.)

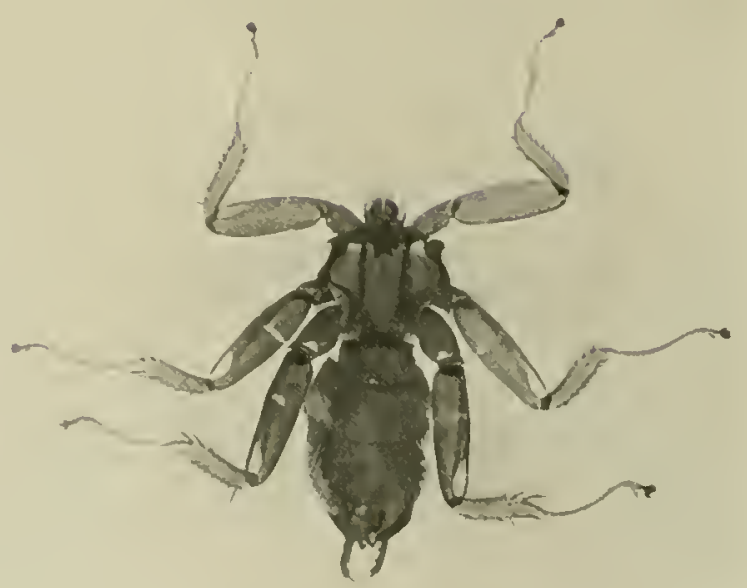

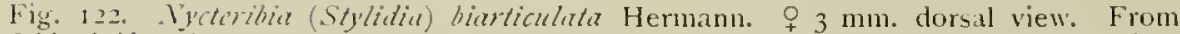
himolophus firrum cquimum. 12 1\% 1912. From micro-slide, Kothschild collection, Tring. (13y permission.)

In Pamsitology' (Uniscrsity l'ress, Cambridge), vol. 1.. no. 4, July 27, 1917, will be found an interestins genctal account of the Nycteribidur, with description of two new genera by 1). Hugh Scott. And in The National Reaicas of Aug. 1919, another account by Mr H. Russell in a paper entitled "Wingless Flies" is of interest to students.

1 am inclebted to Dr Scott for the names of the three Britisl Nyctiribitilue illustrated in

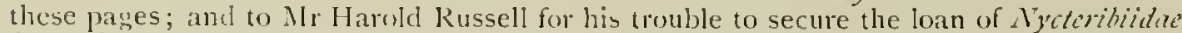
for my illustrations. It should be here stated that blusii and pediculariu are "not absolutely identical," but 1)! Scott considers the difference insufficient to entitle the former to specific rank, but rather tlat they should be looked upon as two forms of the same species.

Sicteribidac of different genera and species have been found not only on the same bat species, but upon the same bat individual (Scott). 


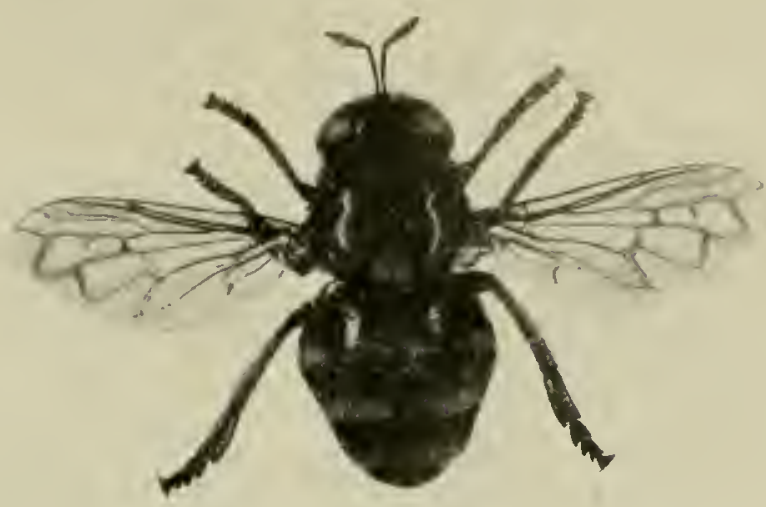

Fìg. 123. ठै.

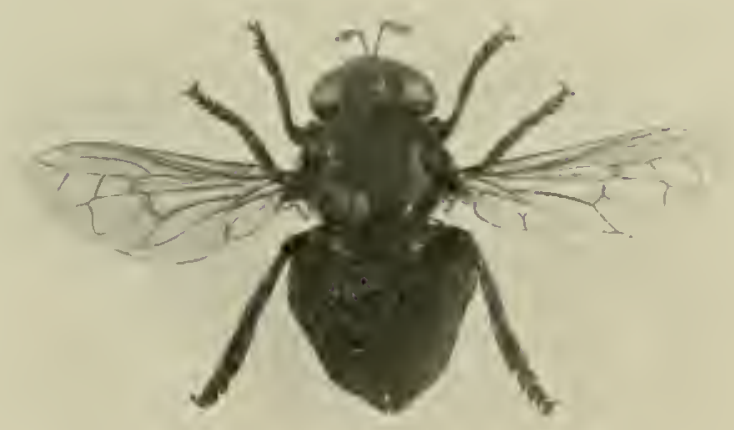

Fis. 124. P.

Figs. 123, 124. Micmion mutabilis L. of $11 \times 20 \mathrm{~mm}$. I'ale silver pubescence across abdomen and on frons. $\hat{f}$ I $\times 21 \mathrm{~mm}$. Golclen tawny pubescence acioss abdomen and on frons. (Bred by Rosse, Butterfield, Yorkshire.) "the larvae found in ants nests and under bark on stumps of trees long cut down, the nest being generally of formicu fusia. Fly emerues middle of May, near Lymington. The wines of bred specimens are often wet and dity from material of nest, generally Ash and Ndridge Hill Pine. Will specimens often have frayed wings." (Jones.) 


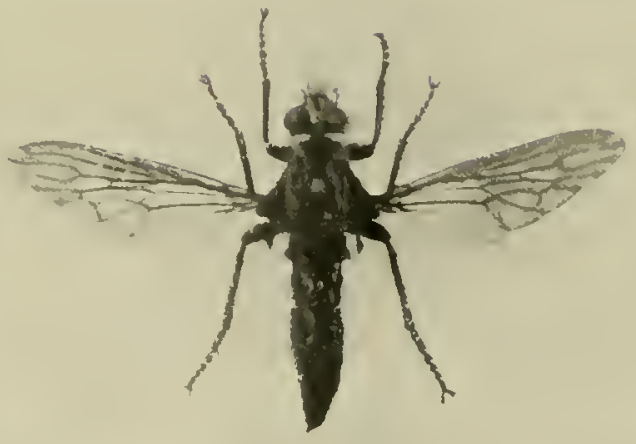

lig. 125. Pumponerus vermunicus L. $\$ 10 \times 36 \mathrm{~mm}$. (P. Harwood, Glamorgan, vi. 1920.) IVings brownish, face bearded: said by Verrall to be dying out in England. Rare. 


\section{INDEX}

The references are to the Figures

Acidia cognata 90

Aciura rotundiventris 89

Acrocera globulus 52

Aedes cinereus 21

Aedes cinereus, antennae of 22

Anacampta urticae 86

Anopheles, ova and liwae 23

Anthrax circumdatus $+6,47$

Anthrax circumdatus, habitat of 48

Balioptera tripunctata 104

Beris vallata 34

Blepharidea vulgaris 68

Bombylius minor 49.50

Borborus equinus 110

Braula caeca 118

Callicera aenea 66

Carphotricha guttularis 96

Ceroxys crassipennis 85

Ceroxys pictus $\delta_{+}$

Chromatomyia ilicis 109

Chrysops caecutiens to

Chrysops sepulcralis $+1,+2,+3$

Chrysotus neglectus 55

Cordylura ciliata 75

Corethra plumicornis $11,12,13$

Corethra plumicornis, laria, pupa it, $15,16,17$

Criorthina floccosa, cocoon 64

Criorrhina floccosa $\sigma_{3}$

Ctenophora ornatia 29,30

Culex vexans, larviı and pupa 24,25

Dilophus febrilis 3

Dixa 26

i) rosophila fenestrarum 107

Drosophila funebris, pupae 108

Elgiva albiseta 70

Empis tessellata $5 j$
Fabricia ferox 70

Fucellia fucorum 74

Gastrophilus equi, pupae 67

Hilara maura 54

Hippobosca equina 113,114

Laphria Hava +4

Limuia marginata 78

Limosina pumilio 111

Lissa loxocerina 82

Liogaster metallina 58

Lipoptena cervi 117

Lonchoptera lutea 56

Loxocera aristata $8 \mathrm{I}$

Nallota cimbiciformis 61

Melangyna quadrimaculata 59

Merodon equestris, pupa 62

Microchrysa polita 33

Microdon mutabilis 123,124

IIochlonyx velutinus is

Mochlonyx velutinus, larva and pupa 19,20

Nemotelus notatus 31

Neottiophilum praeustum 77

Neuroctena anilis 76

Nycteribiiclae 119, 120, 121, 122

Odontonyia tigrina 32

Oponyza florum 105

Palloptera decempunctati 102

l'alloptera umbellatarum 101

Pamponerus germanicus $\quad 125$

l'ericoma compta 8

l'hilonicus albiceps 45

l'hora opaca 112

l'horbia cepetorum 73

l'iophila casei 106

pipunculus furcatus 57

Plityura marginati I 
Psila fimetaria So

Psychoda phalaenoides 9

Psychoda sexpunctata to

Pteropaectria frondescentiae $8_{3}$

Rivellia syngenesiae 87

Scatopse notata 2

Scenopinus fenestralis $5 \mathrm{I}$

Seoptera vibrans 88

Simulium cinereum, ova 4: pupa 5 larva 6 : habitat of 7

Sphenella marginata 95

Spilogaster Zoë 72

Spilographa \%oë 9 I

Stenopteryx hirundinis 115,116

Stomoxy's calcitrans $7 \mathrm{I}$

Syrrittri pipiens 65
Tabanus autumnalis 36,37

Tabanus autumnalis, halsitat of 39

Tabanus autumnalis, mouth parts of 38

Tachina grossa 69

Tepluritis bardanae 100

Tephritis hyoscyami 98

Tephritis plantaginis 97

Tephritis vespertina 99

Therioplectes micans 35

Tipula marmorata 27

Trypeta cornuta 92

Toxoneura muliebris 103

Urophora solstitialis 93

Urophora stylata 94

Vulucella pellucens 60

Xiphura nigriconis 28 


$$
\text { . }
$$

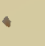



QL532 P35 1921 Ent.

AUTHOR

Pearce, Ethel Katherine

TITLE

Typical flies

\begin{tabular}{|l|l|}
\hline DATE DUE & BORROWER'S NAME \\
\hline & \\
\hline & \\
\hline
\end{tabular}


